\title{
PALEOGRAFÍA GALLEGA. ESTADO DE LA CUESTIÓN
}

\section{ÍNDICE}

0. Paleografía gallega o Paleografía en Galicia.

1. Ámbito crono-geográfico. Justificación.

2. Las fuentes codicológicas y documentales: Información general.

3. Los ciclos de escritura.

3.1.- El ciclo romano-suevo y su repercusión en Galicia.

3.2.- El ciclo visigótico.

3.2.1.- Los códices.

3.2.1.1.- Los testimonios documentales.

3.2.1.2.- Los que pudieron haber sido...

3.2.1.3.- "Colligere fragmenta»...

3.2.2.- Los documentos. Información general.

3.2.2.1.- La periodización morfológica.

3.2.2.1.1.- Etapa inicial "littera antiqua».

3.2.2.1.2.- El siglo XI.

3.2.2.1.3.- La transición caligráfica y la influencia carolina.

3.2.2.1.4.- Los antiquissima.

3.2.2.1.5.- Los novissima.

3.3.- El amplio ciclo carolino (siglos XII-XIII ${ }^{2}$ )

3.3.1.- El "Scriptorium" de Compostela.

3.3.2.- Las producciones codicológicas del ciclo.

3.3.3.- La producción documental.

3.3.3.1.- La carolina estricto «sensu». Morfología.

3.3.3.2.- Las escrituras minúsculas diplomáticas. Morfología.

3.4.- El ciclo gótico.

ra.

3.4.1.- La escuela compostelana en torno al arzobispo don Berenguel de Landoi-

3.4.2.- La producción codicológica. Siglos XIII-XIV.

3.4.3.- La escritura documental. Siglos XIII ${ }^{2}$-XIV.

3.4.3.1.- Los orígenes del notariado en Galicia y el uso del idioma gallego: Sus incidencias paleográficas.

3.4.3.2.- Las distintas formas gráficas del ciclo.

3.5.- El siglo XV.

3.5.1.- Bibliotecas y códices del siglo XV.

les.

3.5.2. - Las grafías de las Actas capitulares, de Concellos y protocolos notaria-

ral.

3.5.3.- La escritura de los documentos notariales y privados. Morfología gene-

4. Líneas de trabajo posibles.

5. Bibliografía. 


\section{PAleografía gallega o PAleOgrafía en Galicia}

Esta es mi primera pregunta: jexiste una Paleografía gallega? Galicia, incorporada al mundo romano desde los primeros siglos de nuestra era, dominada entre los siglos V y VI por los suevos y luego los visigodos, participó de la civilización y cultura clásicas romanas en la medida en que éstos pudieron penetrar entre las tradiciones indígenas.

Escasamente ocupada por los árabes y liberada muy pronto de su dominio, compartió los afanes de la recuperación territorial y de la continuidad cristiana con el reino de Asturias primero, y con el de León-Castilla después, sin que ello impidiese frecuentes rebeliones y un espíritu individualista de nuestra nobleza.

En tales condiciones históricas no se puede hablar en el campo cultural de un apartamiento de las corrientes del mundo hispano occidental, máxime si se tiene en cuenta la influencia receptora y animadora que supone Santiago en los siglos medios y el europeismo de la Peregrinación jacobea.

Por ello, más que de una Paleografía gallega, debemos hablar de una «Paleografía en Galicia».

\section{1. ÁMBITO CRONO-GEOGRÁFICO. JUSTIFICACIÓN}

Necesito justificar brevemente los parámetros en los que me voy a mover. Desde el punto de vista geográfico me ceñiré a la Galicia actual, no a la histórica, cuyos límites han sido variados y cuya influencia en el norte de Portugal es manifiesta en los primeros siglos medievales a través de la archidiócesis de Braga.

En lo cronológico remataré mis consideraciones en los primeros años del reinado de los Reyes Católicos, porque, si con anterioridad cabe hablar de escrituras con características autonómicas ayudadas por el empleo de un idioma propio, la centralización administrativa patrocinada por los monarcas acabó definitivamente con las diferencias idiomáticas y gráficas, mediante la difusión entre nosotros de un notariado y de una administración regida en muchos casos por gentes foráneas.

Los comienzos históricos se fijan en el ciclo de la escritura visigótica, con el inicio de la Reconquista, aunque haré una escueta referencia a la situación anterior romano-sueva, como antecedente obligado. 


\section{LAS FUENTES CODICOLÓGICAS Y DOCUMENTALES: INFORMA- CIÓN GENERAL}

Reservo las primeras por su exigüidad para los respectivos lugares '. En cambio, me parece conveniente dedicar atención a las fuentes documentales, que son muchas y variadas.

Aun a trueque de repetir lugares de procedencia ya conocidos, indicaré sucintamente las que podemos considerar a nuestro propósito.

\subsection{AHN de Madrid.}

Según información suministrada por Sanchez Belda en la Guia del Archivo Hitórico Nacional, la Serie más importante a nuestro propósito es la de «Clero y Ordenes monásticas». En lo referente a Galicia la provincia de la Coruña, la menor en número de documentos conservados, custodia 1223 pergaminos originales o copias, cuyos límites cronológicos van desde al año 862 hasta finales del siglo XV. Entre los centros con mayor representación destacan los monasterios de Santa María la Real de Sobrado (549 documentos); Santa María de Monfero (268 d.); San Payo de Antealtares de Santiago y sus anexos (118 d.); y San Martín Pinario, también de Santiago (89 d.).

Los fondos correspondientes a la provincia de Lugo son los más ricos y totalizan más de 6.000 documentos en pergamino en el tiempo estudiado por nosotros, siendo el más antiguo uno supuesto del año 662. Por su volumen destacan en primer término la propia Catedral con 1795 documentos, seguida de los monasterios de San Julián de Samos (1207); Santa María de Meira (1055 d.); Santa María de Ferreira de Pallares (498 d.). Los más numerosos de ellos corresponden a los siglos XIII-XV.

La provincia de Orense está representada por 2.465 piezas documentales de 18 entidades monacales o parroquiales, de las que sobresalen Santa María la Real de Osera con 936 documentos; le sigue Santa María de Melón (815 d.) y Santa María de Montederramo (467 d.).

Su distribución cronológica va desde el año 715 hasta el límite de nuestra cronología y destacan por su número los pertenecientes al s. XIII, con 1.125 unidades.

Por último, la provincia de Pontevedra conserva en este Archivo 2.246 pergaminos referidos a nueve entidades eclesiásticas, entre las que destacan Santa María de Oya con 1.106 documentos y Santa María de Armenteira con 636; siendo el siglo más documentado el s. XIV, con 953 pergaminos y el siglo XIII con 723.

A ellos deben añadirse los Tumbos y Cartularios custodiados en la Sección de «Códices», entre los que debo destacar por su importancia: el Tumbo Viejo 
de la Catedral de Lugo, y los monásticos de Caabeiro, Xubia, Sobrado y Toxosoutos en la provincia de la Coruña; Lorenzana en la de Lugo; y Celanova y Osera, en la de Orense ${ }^{2}$.

\subsection{ARG de la Coruña}

Aunque su documentación pertenece a la época moderna ', los sucesivos archiveros que han tenido a su cargo la conservación de este archivo han ido desglosando de los pleitos y expedientes mantenidos por cabildos, monasterios y concejos, así como los particulares, los documentos en pergamino que en su momento sirvieron como piezas justificativas; y así, a partir de una primera donación hecha por el archivero D. Andrés Martínez Salazar de 363 documentos, se fueron incrementando otros 527 en la forma dicha, con una distribución que se agrupa así: a) Documentos reales, con 13 pergaminos desde el año 886 hasta 1409; b) Documentos pontificios, con Bulas y Breves en número de 10, de los años 1414 a 1536; c) Documentos particulares de monasterios con 437 piezas de los años 867 a 1556 y 35 entidades representadas; e) Cabildos catedralicios, con 10 pergaminos de 1399 a 1557, correspondientes a Lugo, Orense y Santiago; y f) Documentos de particulares, con 401 pergaminos, de los años 953 a 1586 , de variada procedencia y contenido.

2.3. Archivos Históricos Provinciales

2.3.1. AHP de Orense. Es, sin duda, el más rico de los Archivos provinciales gallegos, en cantidad y calidad de sus fondos. Los que nos afectan directamente se agrupan en la Sección IX, Diplomas, que está constituida por documentos procedentes de varias instituciones eclesiásticas y civiles en número de 798 piezas documentales, distribuidas cronológicamente entre los años 974 y 1866.

Están agrupados en las siguientes Series: a) Monasterios, conventos e iglesias, con 618 pergaminos de los años 974 a 1709, que representan a 24 entidades institucionales, entre las que destacan los 218 de santa María de Oseira y los 102 de San Salvador de Celanova; b) Órdenes Militares, con 75 documentos de tres instituciones, de las cuales la más representativa es la de la Encomienda de Beade con 71 documentos entre 1287 y 1866; Ayuntamiento de Orense, con 31 pergaminos de los años 1309 a 1866; d) Casa del Marqués de Leis, con 30 documentos de los años 1313 a 1543, entre ellos seis del Cabildo de la Catedral de Orense ${ }^{4}$.

A ellos hay que añadir la importante Sección Municipal, que en su Serie de Gobierno recoge, por lo que se refiere a la ciudad de Orense, Libros del Concejo;

2 Luis SÁnCHez BeldA, Guía A.H.N., Madrid, D.G. de Archivos y Bibliotecas, 1958; especialmente, pp. 40-42 y 164-171.

3 Antonio GIL Merino, ARG, Guia, Madrid, 1976., passim.

${ }^{4}$ Olga Gallego DomíngueZ, AHO, Orense, 1977, passim. También tríptico reciente $(1985)$ con anotaciones interesantes. 
notas de escribanos y otros pertenecientes al s. XV y que han sido en parte editados bajo el epígrafe "A cidade e o concello de Ourense»".

Y por último los correspondientes a la Sección VI, Protocolos notariales, que en lo referente a la Serie 6, Partido de Orense, comienza en el año $1484^{\circ}$.

2.3.2. AHP Pontevedra. Menos rico en documentación medieval que el de Orense, advierte el autor de la Guía de este Archivo que «las únicas piezas medievales conservadas, que forman parte de la Sección de "Varios» son una serie de pergaminos recuperados en su mayoría de encuadernaciones de protocolos...'"

De esta sección de Varios hemos de destacar algunos fragmentos visigóticos de los que luego hablaré y un grupo de escrituras relacionadas con la ermita de Santa María de Castro, feligresía de Soutolongo, de los años 1449 y siguientes; más una serie de hojas sueltas de libros litúrgicos y manuscritos leccionarios, breviarios y misales de los siglos XII al XV, con un total de 20 unidades $^{8}$.

Interesan también algunas piezas de la Sección 2:; Archivos municipales, especialmente la serie a) Régimen general, Señorío arzobispal, con documentos del siglo XV; y la serie b) Vida municipal con algún documento del año 1438 en la sibserie de Alcaldes.

Y por último la Sección de Hospitales, 4.", con la serie Hospital viejo de Pontevedra; documentación sobre la historia y privilegios de la Cofradía de nuestra Señora con documentos desde al año 1489, y la gremial de la Sma. Trinidad, que conserva el «Libro viejo de escrituras de testamentos, de donaciones y foros. Años 1411 a 1469", devuelta en la actualidad a sus dueños, pero que estuvo en este Archivo?.

' Este artículo corresponde al tomo II de la obra de Ferreiro Couselo, $A$ vida e a fala dos devanceiros, Vigo, 1967.

${ }^{6}$ La relación completa de estos libros es: I. Notas de Alvaro Afonso dos anos 1432 a 1434, con 137 folios; y notas de Alfonso Anríquez (folios 198 a 212) desde 4 de enero de 1469 hasta 28 de enero de 1470. II. Notas de Alvaro Afonso dos anos 1438 a 1441, 93 folios; III. Notas de Alvaro Afonso dos anos 1442 a 1448, 121 folios; IV. Notas de Alvaro Afonso dos anos 1448 a o 1455, 198 folios; V. Notas de Alvaro Afonso dos anos 1455 a 1456, 164 folios; VI. Notas de Alvaro Afonso dos anos 1457 a o 1459, 81 folios; VII. Registro de Iohan García do ano 1484, con 327 folios; y VIII. Libros das obras da Ponte de Ourense dos anos 1433 a o 1438, 97 folios. Este conjunto se conoce con el nombre de «Libros de notas de Concello", "Libros de notas e Autos de Negocios do Concello", "Libros de acordos», ou "Rexistro do Concello». Ver también, Olga GALLEGo DOMÍNGUEZ, El archivo del concejo de la ciudad de Orense, «Boletín Auriense», 11 (1981), pp. 177-194.

' Pedro LÓPEZ GÓMEZ, A HP Pontevedra, Guia, Madrid, 1977, passim. Especialmente en pp. 29-30.

${ }^{8}$ Ibídem, pp. 135-139, 61-61.

9 Ibídem, p. 84. 
2.3.3. AHP Lugo. Tiene escasa representación documental del medievo y está compuesta por 11 pergaminos procedentes del Archivo Municipal y dos hojas en papel de finales del s. XV. Todos los documentos son reales y afectan sólo indirectamente a nuestro propósito. Sus fechas extremas se sitúan entre al año 1177 y 1420. Destacan, además, en este Archivo algunos fragmentos visigóticos, de los que luego haré mención ${ }^{10}$.

\subsection{Archivo de la Universidad}

Ligado a la Historia de esta Institución, corre parejo a sus vicisitudes con abundante documentación a partir del siglo XVI.

No obstante, dentro de él y dada la estructura que tiene actualmente, cabe distinguir dos fondos diferenciados: uno el de la Universidad, al que antes he aludido; y otro, el histórico local con algunas series importantes a nuestro propósito, como son la del Archivo del Hospital de los Reyes Católicos, depósito de la Excma. Diputación Provincial, con algunos documentos pertenecientes a los siglos medios y procedentes de dotaciones asignadas a este Instituto benéfico-religioso "; la serie segunda, Religiosos o de Culto, con algunos documentos incluidos del siglo XV; y la serie 7, Colecciones documentales facticias, formada por documentos en pergamino, procedentes del antiguo monasterio de san Martín Pinario y un gran número de piezas documentales procedentes del Patrimonio antiguo de la Universidad. En total, esta serie sobrepasa con mucho los 400 documentos y ha de ser incrementada con la revisión a la que actualmente está sometido el Archivo. ${ }^{12}$.

\subsection{Archivos municipales}

Aparte de los depósitos que algunos Ayuntamientos tienen en los Archivos Provinciales, he de destacar la aportación que nos puede prestar el Archivo municipal de Santiago, al que actualmente pertenece el Libro de consistorios del s. XV, no hace mucho tiempo recuperado para el mismo por el archivero D.

10 JiMÉnEZ, Guía, p. 96.

1 El Inventario de los fondos de este Archivo ha sido publicado por José María Fernández Catón. El Archivo del Hospital de los Reyes Católicos de Santiago de Compostela. Inventario de fondos, Santiago, Universidad, 1979. Especialmente p. 729.

12 De este Archivo hay un tríptico publicado por la Directora encargada del mismo y a él referimos la nomenclatura y número de las Secciones. Los pergaminos del antiguo Fondo de San Martín Pinario han sido catalogados y publicados por LUCAS ÁLVAREZ, cf. Bibliografía; y los del fondo de Patrimonio de la Universidad, después de un primera redacción del Catálogo en 1948, por LUCAS ÁlvareZ, han sido publicados por LUCAS. M,-JUSTO, M. XORÉ,-LuCAS DOMINGUEZ, P. Forites documentais du Universidad de Santiago de Compostela. Pergameos da Sescè BENS de Arquivo Universitario (Anos 1237-1537). (Edeuin diplomatica) ep. tambien: JUSTO MARTín, M. XORÉ, Arquivo Histórico Universitario. Quia Santiago, Universidad [1990]. 
Angel Rodríguez González. Por lo demás, el archivo de Santiago es rico en documentación de la época moderna ${ }^{13}$.

2.6. Museos

2.6.1. Pontevedra. Guarda este Museo provincial en su Sección de documentos los de la Colección Sampedro y otras adquisiciones con un total de 50 documentos de los siglos XIII y XV. También pertenecen a él los documentos del Gremio de Mareantes con 39 documentos de los siglos XII a XV; un libro de Acuerdos, o Livro do Concello, del ayuntamiento de Pontevedra del año 1436; un Minutario notarial, incompleto, de los años 1434-1435; y otras aportaciones que constantemente van enriqueciendo los fondos de esta Sección ${ }^{14}$.

Recientemente y gracias a una paciente labor de revisión de encuadernaciones de libros antiguos, el Museo ha podido ver incrementados sus fondos en pergamino con fragmentos de códices medievales, alguno visigótico, del que daré cuenta en su lugar.

2.6.2. Museo de Lugo. Guarda entre sus fondos 12 documentos pertenecientes uno al s. XIV y otros once al siglo $\mathrm{XV}^{13}$.

2.7. Archivos ecleiásticos

2.7.1. Catedral de Santiago. Aparte de una colección no my abundante de documentos, en la que predominan los de los siglos XIV y XV, las aportaciones paleográficas del archivo catedralicio se centran en sus Tumbos $y$ algunos libros manuscritos del s. XV.

El Tumbo A, escrito en el año 1129, que destaca por su primorosa decoración y contiene copias de documentos reales; el Tumbo B, escrito en el s. XIV, con un contenido similar y más amplio que el $\mathrm{A}$; El Tumbo $\mathrm{C}$, dividido actualmente en dos volúmenes y realizado también en el s. XIV, con documentos de diversas procedencias, especialmente de capitulares; Los Tumbos D., E, F. G. y H, todos con documentos varios de los siglos XIV y XV. Los Libros I y II de las Constituciones, escrito el primero en el s. XIV y el segundo con documentación de los siglos XIV y XV; el Tumbo Viejo de Aniversarios, número 1, con documentos del $\mathrm{s}$. XV y el núm. 2 y 2 bis, también con documentación del mismo siglo; La serie de Actas Capitulares que dan comienzo regularmente a

${ }^{13}$ El Prof. Ángel RodrígueZ GonZÁlez, antiguo Director de este Archivo, tiene preparado un Estudio y edición de este Libro de Consistorios.

${ }^{14}$ Información sumaria en JiMÉnEZ, Guia, p. 104. Cf. también J.F. FILGUEIRA VAlverde, Archivo de Mareantes, Pontevedra, 1946; y Enrique FernándeZ-Villamil ALEGRE, Documentos medievales del Museo de Pontevedra, siglos XIl y XIII; Id. del siglo XV, etc. en Bibliografía. RODRíGUEZ GONZALEZ A.-MILLAS, Joidero, Documentos para a Historia de Pontevedra medieval. «Livro de Concello de Pontevedra (1431-1453). Museo de Pontevedra, (1989).

is JimÉnEZ, Guia, pp. 103-104. 
mediados del siglo XV, a partir de 1465; y el Tumbillo de Tablas, privilegios y constituciones, escrito en el s. XIV ${ }^{16}$.

2.7.2. El Archivo Diocesano de Santiago. Fondo de San Martín Pinario. Aparte de la documentación de este monasterio que se encuentra en el AHN, y en el Archivo universitario, custodia el diocesano varios libros de instrumentos judiciales y notariales, apeos, juros, presentaciones de beneficios, etc. que pertenecieron al citado monasterio y se encuadran entre los escritos del s. XV; así como algún libro-registro de documentos del convento de Santa Clara de Santiago; y una colección apreciable de documentos sueltos desde el siglo $\mathrm{X}$ al XVI ${ }^{1}$.

2.7.3. El Archivo de la Catedral de Lugo. Muy rico en su tiempo, está hoy desmembrado entre el AHN y el propio Archivo catedral. De la documentación medieval nos afectan una colección de 166 documentos que van del el s. IX al s. XVI, de los cuales una buena parte son reales o pontificios; así como los libros de Actas capitulares, que pueden seguirse parcialmente desde mediados del s. $\mathrm{XV}^{18}$.

2.7.4. Archivo de la Catedral de Mondoñedo. En el fondo de documentos sueltos conserva 152 pergaminos comprendidos entre los s. IX y el XV ( 1 , del s. IX; 11 del s. X; 1del s. XI; 23 del s. XII; 25 del s. XIII; 59 del s. XIV y 32 del $\mathrm{s}$. $\mathrm{XV}$, entre originales y copias). Se añaden a este fondo otros 24 documentos procedentes del monasterio de Pedroso, que corresponden a los siglos XIII-XV. Por último se custodia también en este Archivo el llamado Tumbo pechado, de los siglos XIV-XV, con abundante documentación contenida en sus 250 folios; y dos Calendarios de los siglos XIII-XIV, con escrituras íntegras o en extracto de documentos notariales y privados ${ }^{19}$.

2.7.5. El Archivo de la Catedral de Orense. «Es escaso en códices, pero rico en documentos», dice el autor del Catálogo de sus documentos en pergamino, Duro Peña. Solamente los pergaminos rebasan los ocho mil, en números redondos... la mayoría de los mismos -6248- está formada por los llamados (1970).

${ }_{16}$ JIMÉNEZ, Guia, pp. 106-108; y Guía del visitante. Archivo de la Catedral, Santiago

17 Cf. sobre este Archivo, Salvador Domato BúA, El Archivo Histórico Diocesano de Santiago de Compostela. Sondeo documental; y Archivo Histórico Diocesano. Inventario del fondo general; JIMÉNEZ, Guia, pp. 114-117.

18 JMÉNEZ, Guia, PP. 118-120; A. GARCÍA CONDE, El Archivo de la Catedral de Lugo, en BCPM Lugo, II-3/4 (1967), pp. 4-12.

19 JimÉneZ, Guia, pp. 120-122; Enrique CAl PARDo, El Archivo de la Catedral de Mondoñedo, «Jornadas», pp. 133-143. El mismo autor acaba de editar la documentación del monasterio de Pedroso. El monasterio de san Salvador de Pedroso en tierras de Trasancos. Colección documental, La Coruña, Publicaciones de la Excma. Diputación Provincial, 1984, $358 \mathrm{pp}$./d. id., Catálogo de los documentos medievales, escritos en pergamino, del Archivo de la Catedral Mondoñedo, (871-1492) Lugo, Diputación Provincial, 1990. 
«pergaminos monacales» procedentes de los numerosos e importantes monasterios orensanos... Pero, aun sin contar con éstos, los pergaminos catedralicios propiamente dichos alcanzan un volumen considerable.

Queda también una documentación en papel anterior al siglo XVI, dispersa y entremezclada con la anterior, que contiene libros, especialmente de Notas $y$ registros de Cancilleres, que forman una serie casi continua desde 1362 hasta mediados del s. XVI.

La documentación, que tiene en sí misma una unidad de procedencia de la iglesia orensana responde a las instituciones morales y jurídicas que se desarrollan dentro de la propia Iglesia: Mesa Capitular, Obra o Fábrica, Clérigos de coro, Cofradía del Crucifijo y Capellanías diversas y por último, la Mesa episcopal ${ }^{20}$.

2.7.6. Archivo de la Catedral de Tuy. Sobre el inventario de este Archivo realizado en 1923 por don Pascual Galindo Romeo se pueden obtener los siguientes datos. Tiene un fondo documental de 372 piezas en pergaminos de los cuales 255 son privados, 105 reales y 12 pontificios, que se extienden cronológicamente desde el s. X hasta el s. XV en la siguiente proporción: 5 , del s. XI; 53 del s. XII; 63 del siglo XIII; 128 del s. XIV; 122 del siglo XV.

Además conserva en el archivo una importante colección de protocolos notariales de los siglos XIV y XV, entro los que destacan las Notas de Pedro de Lagea, con documentos de los años 1328 a 1349, y las de Fernando Eans, con documentos de 1323 y $1325^{21}$.

2.7.7. Archivo del monasterio de san Payo Antealtares de Santiago. Reorganizado en estos últimos años, conserva una buena colección de documentos en pergamino procedentes de los distintos cenobios que en el s. XVI constituyeron la unidad monástica femenina que todavía subsiste. Aparte de la documentación de este monasterio conservada en el AHN., tiene «in situ» algunos documentos medievales procedentes de los monasterios de Sobrado de

20. Emilio Duro Peña, Catálogo de los documentos privados de la Catedral de Orense,/d. Catálogo de documentos reales del Archivo de la Catedral de Orense «Miscelanea de Textos Medievales" 1, (1972), q-145 pp. 7-11; JIMÉNEZ, Guia, pp. 122-124; Eladio LeIrós FERNÁNDEZ, Catálogo de los pergaminos monacales, 1951, passim.

2 Jiménez, Guía, pp. 124-126; Pascual GALINDO ROMEO, Tuy en la baja Edad Media (siglos XII-XV), Madrid, 1923, pp. 159 y ss. en especial; Las notas de Pedro de Lagea han sido estudiadas por María Guadalupe POSADA, Documentos del notario Pedro de Lagea para la Catedral de Tuy (Tesis de licenciatura, inédita).

La relación de protocolos es la siguiente: I, 1323-1325, Fernando Eans; II, 13281349, Pedro de Lagea; III, 1340-1344, Sancho Eans; V, 1367-1390, Muño González; VI, 1413-1426, Juan Rodríguez; VII, 1417, Juan Rodríguez; VIII, 1418-1427, Juan Rodríguez; IX, 1445-1449, Juan Rodríguez; XII, 1449-1464, Fernán González; XIII, 14591464, Alonso Fernández; XIV, 1466-1467, Alonso Fernández. 
Trives, Alveos, Camanzo y, sobre todos, Ramirás. De Camanzo se conservan actualmente 74 documentos que en su tiempo estuvieron divididos en dos mazos desde el año 1096 hasta mediados del s. XVI; y del segundo quedan todavía 681 documentos, de los que actualmente se guardan 32 en el AHN; 11 en el fondo monástico de la Catedral de Orense y el resto en el propio Archivo. Estaban distribuidos en 13 mazos de 50 pergaminos cada uno, más un mazo 14 con sólo 31 documentos. De ellos se han perdido hasta el presente un $24,9 \%$ aproximadamente, lo que supone una merma de unos 169 documentos. Sus fechas oscilan entre los años 1017 y el siglo XVI ${ }^{22}$.

2.7.8. Archivo del Convento de San Francisco. Santiago. Procedentes del convento de Santa Clara de la misma ciudad, guarda el archivo franciscano una buena colección de documentos medievales, que completan las series que actualmente se guardan en el Archivo diocesano, y en el Archivo universitario en su Serie de Clero y Religiosos ${ }^{23}$.

2.7.9. Pequeños fondos documentales pueden encontrarse todavía en algunas instituciones o particulares; así la colección que guarda la Real Academia Gallega, o la que custodia la Fundación Penzol, de Vigo, o algunos particulares, con colecciones menos controladas, aunque conocida alguna de ellas. Pero no haremos mención especial de las mismas, para no alargar en exceso este apartado ${ }^{24}$.

\section{LOS CICLOS DE ESCRITURA}

\subsection{El ciclo romano-suevo y su repercusión en Galicia.}

Prácticamente sin estudios desde el punto de vista paleográfico y con documentación exclusivamente epigráfica, menciono este ciclo para llamar la atención sobre la importancia que puede tener el análisis de las inscripciones conservadas y que han sido reunidas en un Corpus ${ }^{23}$. El análisis de tales

${ }^{22}$ He dedicado especial atención a este Archivo y su ordenación. Los fondos de Camanzo han sido estudiados por mí en la Colección Diplomática de San Salvador de Camanzo, "Archivos Leoneses», 64 (1978); y los de Ramirás en el Archivo del monasterio de San Pedro de Ramirás en la Edad Media, "Compostellonum», 1-4 (1981) y LUCAS, M,-LUCAS Domínguez, Pedro, San Pedro de Ramirez. Un monasterio femenino en la Edad Media. Colección Diplomática. Santiago, Caixa Galicia, 1988 DuRo PEÑA ha estudiado los monasterios de Ramirás y Sobrado de Trives, haciendo uso en buena parte de la documentación de este Archivo.

${ }^{23}$ Estudio sobre estos fondos en María Gloria EIJÁn MOYANO, Monasterio de Santa Clara de Santiago de Compostela (tesis de licenciatura).

24 Información sobre estos fondos en JIMÉNEZ, Guia, pp. 126-127.

${ }^{25}$ Cf. en la Bibliografía. Inscripciones romanas de Galicia. También F. ARIAS VILAS y otros, Inscriptions romaines de la province de Lugo; y F. ACUÑA CASTROVIEJO, Bibliografía de Galicia romana, Lugo, 1977. 
inscripciones puede resultar interesante al hilo de la metodología diseñada por Jean Mallon en muchas de sus publicaciones ${ }^{26}$; y tal estudio nos podría, quizá, permitir la detección de tipos de escritura no considerados hata el presente entre nosotros, por ausencia de testimonios comprobados.

Por el momento, sólo conozco el estudio de Josefina Castro Vázquez, Contribuciones a la tipología epigráfica de la Gallaecia romana, tesina de licenciatura defendida en la antigua Facultad de Filosofía Letras de Santiago y que se ciñe a las escrituras epigráficas del Museo de Lugo, con una tipología que sólo abarca los primeros siglos del cristianismo ${ }^{27}$.

El tema, pues, puede ser un punto de partida para ulteriores investigaciones.

\subsection{El ciclo visigótico}

3.2.1. Los códices. En el año 1952, en trabajo no acabado, escribía a este propósito que una de las dificultades existentes para analizar la escritura de Galicia durante el período visigótico era la total ausencia de documentos gráficos de tipo codicológico. Los años transcurridos han hecho cambiar el panorama, si no radicalmente, al menos con mayor esperanza de fundamentar este período sobre textos conservados, aunque éstos sean fragmentarios y tardíos.

Cuanto podemos saber actualmente sobre este tema ha sido recogido magistralmente por el Prof. Díaz y Díaz en una reciente monografía titulada Códices visigóticos de la Monarquía leonesa ${ }^{28}$. A ella me atendré en los apartados que siguen.

3.2.1.1. Testimonios documentales. Una de las formas de concer la producción libraria de tiempos pretéritos es el análisis de los documentos coetáneos y el descubirmiento a través de ellos de posibles referencias a libros. De la documentación consultada por Díaz e incrementada por mí en el recientemente estudiado y reaparecido Tumbo de Samos, resultan no menos de 40 menciones documentales en las que se citan específicamente libros, y ello sin contar con otros textos en los que se alude a ellos de forma genérica ${ }^{29}$.

26 Colección reciente de sus trabajos. Jean MALLON, De l'Écriture, Recueil d'études publiées de 1937 à 1981. Éditions du CNRS, París, 1982, 367 pp.

27 Aparte de la monografía citada aquí, cf. de la misma autora y con el mismo título en BCPM, Lugo, IX (1973), pp. 145-150.

28 Díaz Y Díaz, Códices, León, 1983.

29 Ésta es la lista de documentos a los que se hace referencia:

854-IV-16. El presbítero Gudesteo concede al monasterio de Samos la Iglesia de San Román y San Mamed de Teixeira con todos sus bienes, y entre ellos libros «manuale, psalterium, ordinum et canicum» (Núm. 2)

867-V-07. El obispo Rosendo dona al monasterio de San Vicente de Almezero 
Resultan en total no menos de 358 manuscritos los que se relacionan en tales documentos y $\mathbf{4 0}$ más, si se admite la mención que hace el texto de 21 de

varias tierras, ganados, objetos de ajuar y libros, id est, beati prosperi, expositum ezequielis, beati pauli epistolas, moralium, passionarium vero et antiphonarium quos communiter cum meis feci germanistam pro illorum quam et pro mea devotione, sic vestre iam dicte ecclesie offero (...) sive libros quod adhuc si vixero faciam et hic prescripsero, id est, ordinum, precum, psalterium, manuales in duas formas diuisum; ...librum etiam beati Iob et expositum de eptatico et regun eeu et glosamatarum in uno corpore conrinentem geronticum...." (Núm. 4).

889-X-24. El presbítero Beato restaura la iglesia de san Salvador de Eiras y le hace donación de sus bienes, "tesauro cum libros, id est, hordinum, commicum, sermonum, manuale, precum, antifonarium et orationum, orario, psalterium, canticorum et hymnorum, orationum, catamatheum, deca psalmorum et ibidem est cum ordinem et letanias apostolicas omeliarum, epistolarum, cannonicorum, vitas patrum, libro iudicum.. libros comico, manual et precum...» (Núm. 9)

890-II-11. Flomarico y otros fundan la iglesia de san Miguel de Negrelos, dándole entre otros bienes «libros ordinum, comitum et passio sancti Christoforis» (Núm. 10)

902-I-01. El presbítero Teodenando concede al monasterio de Samos la vila e iglesia de Adilaní, fundada por su ascendiante Egilan; entre los bienes figuran «libros eclesiasticos, id est, comicum, adiunctum in uno corpore, uirginitatem sancte marie, vitam sancti martini, librum beati iob, orationum, passionum, ordinum omnimodum, antifonarium, horarum et precum un una forma...»(Núm. 13)

904-IX-01. Sisnando, obispo de Compostela, repite la dotación fundacional de san Sebastián de Monesacro, al que ofrece, entre otros bienes... «libro s ordinum, sacerdotalem I, ieronticon I, tertium cum suo officio, idem martinis sancti sebastiani passio et missae, psalterium, orationum, commicum et manualium...»(Núm. 14)

910-V-12. El abad Adalino da al presbítero Leovigildo la iglesia de san Julián de Friol, con todas sus pertenencias, entre ellas «libros II manuales, salterium, cantigorum et imnorum, horationum, sermonum et pregum, ordinum et liber spiritalicum antifonalum...» (Núm. 16)

916-VIII-17. Ordoño II y Elvira conceden al monasterio de san Salvador de Léreza, además de unas heredades «libros sacros missales, officiales, antiphonarios et psalterios et regulan scriptam sancti benedicti, cum omnibus ornamentis...» (Núm. 18)

922-II-27. Ordoño II cambia a la iglesia de Santiago las vilas de Alcabra y Oza por la de Láncara, recibiendo en oferción «libros ecclesiasticos, antiphonarium, commicum perfectos, orarium cum prece...» (Núm. 21)

922-VIII-01. Ordoño II confirma la fundación de san Julián de Samos y lo dota con libros eclesiásticos, id sunt: antiphonarium, orationumcomicum, manuales duos, psalterium, passionum duos, orationum, ordinos duos, precum; libros spiritales, id est, homeliarum, dialogorum, homelia prphetarum, dispositio esaye prophete, parte de morario, degada psalmorum, textum euangeliorum, librum regularum, genere officiorum, scrinonimarum, epistolarium, ethimologiaru, abticum, laterculum in sancto christophoro de Lancara antiphonarium, orationum, comicum, duos manuales et psalterium..." (Núm. 23)

923-XIII-08. Félix, presbítero, dona a la iglesia de Santiago de Samassas, además de otros bienes «libros psalterium, comicum, orationum, ordinum, manualium et precum...» (Núm. 24) 
enero de 1009, et libros spiritales quadraginta. En este número están ampliamente representados: Antifonarios, Oracionales, Cómicos, Salterios, Horarios,

933-II-13. Osorio y Argilona conceden al abad Odorico y al monasterio de san Fiz y los Macabeos el lugar que ocupaba el cenobio y libros «ordinem, continentes antiphonarium, orationum, comitis, manualium in uno corpousculo coniunctum et psalterium, cantidorum, himnorum et alium ordinum de collectum..." (Núm. 31)

936-III-15. Los obispos san Rosendo y Ero, los bades Rodrigo y Anagildo y el clérigo Sigualdo donan a san Juan de Caaveriro... «et omne libros, quos ibi dedimus atque conocedimus pro animabus nostris, id sunt, psalterium, ordinum orationu, manual, psalteriolo, explanatio zmaragdi, omeliarum, sententiarum, dialoquorum, timologiarum, geruntiquorum, prosperi, prenosticorum, glosematarum, partem libri moralii usque in libro quinto, octo vicia, questionum, regula beati benedicti...» (Núm. 32)

938-II-27. Ilduara Eriz, madre de san Rosendo, hace una donación al monasterio de Celanova y entre otros bienes le concede «II libros, salterio I et goticum $1 .^{\circ} \ldots$ (Núm. 33)

938-V-31. El abad Adelfio dona a su monasterio de Samos, entre otras cosas, «libros antisimen... preter alios quos hic invenimus...» (Núm. 34)

942-IX-26. Consagración del monasterio de Celanova, al que dota san Rosendo, entre otros bienes, «libros ecclesiasticos, hordinum, psalterium, antiphonarios II, orationum, comicum, manual, precum; alios spiritales, biblioteca, moralium, dialogorum, pastoralis, ezequielem, ethimologiarum, sententiarum, epistolarum, ingerarum egerie, storia ecclesiastica, ebtamarum, geronicum, expositio trinitatis et collationum...» (Núm. 35)

947-I-05, Genitrigo, presbítero, edifica y dota la iglesia de san Salvador de Flavelo, en sus propias tierra y le concede... «libros prenominatos, manualium, psalterium, commicum, ordinum..." (Tumbo de Samos, fol. 84 r., escritura 226)

951-I-23. Fafila, confeso, dona al monasterio de san Vicente de Louredo varias vilas y otros bienes, entre ellos, "libros prenominatos psalterio, commicum et sermonum in unum, manuale, antifonarium, passionum inquoatum, regularium et geronticum; adicimus ibidem alios libros ecclesiasticos antiphomarium, manualium, ordinum, orarium, precum, libellus de uirginitate sancte marie virginis siue et senonimarum...» (Núm. 40)

955-XII-30. Sisnando, obispo de Santiago, y su padre el confeso Hermenegildo, donan al monasterio de Sobrado: «igitur offerimus... libros antifonarios duos integros atque perfectos, orationos II integros, manualium integrum, comitum integrum, passionum, psalterium cum psalmis, canitcis et himnis, hordinos II unum episcopalem et alterum mihorm, precum, orarium in uno corpore; vitas patrum, sinonimiarum, regularum, institutionum et octo vitia in unum.." (Núm. 41)

963-VI-24. En la donación hecha al monasterio de Santa Leocadia de Guillade por Menendo se incluyen: «isto libro místico per sic... duos libros, I hordino perfecto et alio libro de $X^{\text {a }}$ usque ad diem sancti petri, I psalterio..." (Núm. 48)

967-X-30. Sisnando presbítero dona a santa María de Barbadelo su herencia en el lugar de Ortoá y, entre otras cosas: «librum goticum, manual, canonicum novum, psalterium perfectum; et in testamento sancti Michaelis: antifanal et orationum, canonicum, manuales et ordinum...» (Tumbo de Samos, fol. 41 v., Escritura 91)

969-VI-17. Se funda el monasterio de san Salvador de Lorenzana y el conde Osorio Gutiérrez le concede «etiam libros antiphonarios, creationum, misticum in duos libros 
Ordinum, Manuales, Precum, Sermonarios, Pasionarios, Místicos y Misales; y en menor número textos bíblicos (Biblioteca o partes de la Biblia), libros de

continentes omnem officium, manualium, commicum, hmnorum, sermonum, passionum, psalterios VII, ordinum, precum, orarium, alium quem continet officium litaniarum...» (Núm. 51)

976-XI-18. La confesa Senior dona al monasterio de san Pelayo de Diamondi varias vilas e iglesias y «libros ecclesiasticos manuale, sermonum, psalteriu, ordinum...» (Núm. 54)

978-VI-29. El presbítero Sediges restaura el monasterio de san Juan de Cova, dádote... «ibidem codices..id sunt, libro antiphonarium, libro beati iohannis osaurei, "penitencie, alium ordinum, de comendatione animarum, sedenciarum: sunt numero VI...» (Núm. 55)

989-IV-30. Menendo Emeteriz, monje, dona a la iglesia de santa María de Triacastela todos sus bienes y posesiones, entre ellos «librum manuale et librum ordinum...» (Tumbo de Samos, fol. 65 v.-66 r., escritura 164)

995-VII-01. El obispo compostelano Pedro de Mezonzo restaura la iglesia monasterial de Curtis, a la que concede «libros escclesiasticos ad anno in annum, antifonarium, orationum, comitum, manualium, precum, psalterium et ordinum». (Núm. 57)

1009-I-21. Vermudo Sunilanez entrega a Samos el monasterio de Santiago de Barbadelo y con él, "libros ecclesiasticos antiphonarium obtimum et perfectum et alias causas bonas et multimodas in ello de multis modis, psalterios duos et plerfectos, manuales duos, orationes unum, ordines tres, libri cogmicum et liber precum, ista sunt que ego per me deci et ganavi; et passiones duas et libros spiritales quadraginta...» (Núm. 59)

1009-I-18. Rodrigo, confeso, ofrece sus bienes a la iglesia de Santiago en la vila de Toldaos, y entre ellos: libros commicum, orationum, ordinum, psalterium, oralio, canticorum..." (Tumbo de Samos, fol. 54 r-v., escritura 129)

1011-XII-02. El abad Aloito y sus hermanos donan al monasterio de santa María de Ribeira diversas posesiones, y ... «adicimus ibidem...libros ecclesiasticos antifonario uno de toto anni circulo, ordino, manastico nimis bono, manualio, psalterius duos...» (Núm. 60)

1019-V-04. La condesa Adosinda Gudesteiz dona al monasterio de san Martín de Lalín y entre los dones figuran: «libros ecclesiasticos psalterios III, antifonarium I ${ }^{\circ}$, comico I ", manualio I ${ }^{\circ}$, ordinos IIII "r, orationum I ${ }^{\circ}$, passionum I ${ }^{\circ}$, regula beati benedicti, liber beati Martini, alio beati agustini, sinonimarum, liber iudicum, canticorum I ${ }^{\circ}$, preco I ${ }^{\circ}$, versario $I^{\circ}$, uirginitatis sancte marie...» (Núm. 62)

1030-IX-O1. El presbítero Dexterigo ofrece a la iglesia de Santiago de Meilán, además de otros bienes: "libros ecclesiasticos, id sunt: librum antiphonarum perfectum, orationum de toto anni circulo, comicum perfectum, compassionis collectas de isitius sanctos superius nominatos (sancti iacobi apostoli, sancti iohannis apostoli et evangeliste, sancti iohannis babtiste, sanctorum apostolorum petri et pauli, sancti martini et confessoris chiristi, sancti Michaelis archangeli, sanctorum iuliani et basilisse, sancti Adriani et natalie, sanctorum cosme et damiani, sancti mameti, sancti stephani levite, sancti benedicti confessoris, sancti pelagii, santi victori et sancte theodosie) et manualium novos et obtimos, oridinos II "s, psalterium cum canticos et librum hymnorum, precum et glosematarum». Num. 66 1042-VII-05. El obispo Pedro de Lugo dpna a su iglesia entre otros bienes: 
Reglas, de Cánones, Vitae Patrum y Geronticum; autores eclesiásticos europeos e hispanos y, entre ellos, repetidamente Isidoro e Ildefonso; y el Liber Iudicum o gothicum mencionado una y otra vez ${ }^{30}$.

Sobre la calidad de tales libros, al menos, de algunos no cabe dudar. Los textos hablan de libros optimos, integros et perfectos, antiphonarium optimum. Luego, si no todos, los spiritales, al menos, debían ser confeccionados con gran esmero.

¿Dónde y cómo se llevaron a cabo? Las referencias documentales señalan reiteradamente las iglesias de Santiago y Lugo y sus áreas de influencia: Picosacro, Iria, Curtis en la primera, Diamondi, San Martín de Lalín, Friol, Samasas en la segunda. Los grandes monasterios de la época, Samos y Celano-

«libros ecclesiasticos oromnum I de toto anni circulo, ordinum speciale I ${ }^{\circ}$, psalterium cum cum canticorum et imnorum perfectum; scerpta canonum I, cronica regum I $2 . . . »$ (Núm. 71)

1043-III-17. El abad Aloito y sus hermanos entregan al monasterio de Celanova el de santa María de Ribeira con todos sus bienes y, entre ellos incluyen: «libros ordino et nimis obtimos, uno de avento et alio sic de auento et de quadragesima, tercio de resurrectio et de quatidiano qui compleret ad ordine de toto anni, manuales duos, et uno antifonalium et duo psalterium...» (Núm. 73)

1043-XI-28. Trudili Suárez concede al monasterio de Celanova el de san Salvador de Sabucedo con todos sus bienes, entre ellos: «libros officiales duos, antifonario nimis obtimo, commicum et manualium...» (Núm. 74)

1036-1054. Noticia de la donación de san Pedro de Laroá hecha por el monje Vimara,... «que fecit ornamenta de ecclesia prenominata, id est: uno libro de sancti aciscli usque ad pascha perfectum, et alio de pascha in sancti martini simili tale, alio III ${ }^{\circ}$ libro de quatidiano perfectum, IIII ${ }^{\circ}$ libro manualio perfecto; $\mathrm{V} \cdot$ libro regula una perfecta et alio libro VI ${ }^{\circ}$ psalterio psalmorum, VII ${ }^{\circ}$ libro de canticos et ymnos et illo medio spirituale, VIII ' libro antifonale, VIIII ' libro ordinum...» (Núm. 77).

1026-I-28. El abad Diego Funda y dota el monasterio de san Antolín «in villa Güimir» y le ofrece entre otros bienes «libros ecclesiasticos, id sunt: ordinumantifonarium, orationum, misticum, canonicum et manualium et psalterium perfecte cum canticis et himnis..." (Tumbo de Samos, fol. 3, escritura 7).

1055-II-14. Ordoño, presbítero, concede a la iglesia de san Vicente de Froián varias heredades y: libros ecclesiasticos, id sunt: ordinum, manualium, antiphonarium, commicum..." (Tumbo de Samos, fol. 78 r., escritura 208).

1037-1066. El obispo compostelano don Cresconio dona a la iglesia de santa María de Iria, entre otras cosas: «librum decretorum I, canones, psalterium p(er)fectum, moralia iob cum exposicione, librum sacramentorum...» (Núm. 80).

1091. En el inventario del abad Fromarico de Samos figuran entre otros bienes. «De libris, id est: antiphonarium I, comitis I cum semonum sanctorum patrum, missales II, breviarium I et ordinum que continet ad salis aspersionem vel ad ordinis infirmorum vel mortuorum..." (Tumbo de Samos, fol. $26 \mathrm{r}$-v, escritura 55) (la referencia numérica se refiere a la obra de DíAz, Códices, pp. 157-174.

30 DíAz, Códices, pp. 178-211. 
va, han merecido incluso el honor de un estudio monográfico sobre sus posibles bibliotecas "; y dentro de sus fondos se citan para el primero los lugares de Barbadelo, Triacastela, San Antolín de Güimil y San Vicente de Froián; y para el segundo Ribeira, Eiras, San Pedro de Laroá, como lugares de existencia o producción de libros.

También el monasterio de Sobrado, y los de san Salvador de Lérez, Caaveiro, San Juan da Cova, Almerezo, Lorenzana y Guillade participan en la geografía codicológica en este período.

El cómo es más problemático. Las noticias que tenemos sobre posibles escuelas son escasas y tardías y sólo cabe sospechar que, tanto las Catedrales como los centros monásticos de primer orden tuvieron, sin duda, escuelas de formación y «scriptoria», en los que se copiaban estos y otros libros y se difundían a los centros menores. Alguna noticia muy tardía nos habla, p. ej., de que en el año 982 un comes Ordonius Velazquiz dedit filio suo Guttier rad nutriendum " ad ipso pontifice Hermegildum... Este obispo era el de Compostela y el término nutrire indica una entrega para educación ${ }^{32}$.

Mucho más tarde, al final de nuestro ciclo, en el año 1095, un salvoconducto expedido por el conde de Galicia don Raimundo está suscrito por Didacus Gelmirici clericus apud sedem sancti lacobi «nutritus», lo que puede ser un buen indicio de la estabilidad de la escuela compostelana para esta época. En épocas fuera de este período recojo del Tumbo de Samos dos noticias de interés. El 29 de junio del año 930 los colonos adscritos a la iglesia de Santiago de Estragiz se ponen bajo el amparo del abad de Samos Adelfio y non...babentes consolationem de sacerdote, nec «doctorem» qui nos docuisset..., texto que podría ser interpretado en el sentido de un magister, aunque la interpretación parece forzada y por ello sólo aludo al testimonio, pero no lo considero apoyo a la tesis de una escuela rural; si bien otro texto del año 1139 nos ofrece a un Pelayo Guistilaz, con sus padres y hermanos, que donan a Samos la iglesia de San Salvador en territorio de Triacastela, y entre los derechos que se reservan dicen: Et si aliquis nostrum (parentum vel propinquorum) voluerit filium suum clericum facere ibi, "doceatur et demonstretur" in ecclesia illa ${ }^{33}$... con una posible alusión a la existencia de escuelas parroquiales ya tardías. Todo ello, sin embargo, simple indicios.

3.2.1.2. Los que pudieron baber sido...

a) Cuando se piensa en códices visigóticos de posible procedencia gallega se va la mente en el acto al famoso Libro de Horas del rey Fernando y de su

"Díaz, Códices, pp. 233-236.

'2 DíAz, Problemas de la cultura..., p. 188, y cita a LÓPEZ FERreiro, HIC., II, apéndice, p. 177.

"Tumbo de Samos, escrituras 170 y 169. 
esposa Sancha, joya que se conserva en la Biblioteca Universitaria de Compostela. Han sido muchos los autores que se han ocupado de él, si bien, como afirma Díaz, «no ha sido nunca objeto de una investigación minuciosa desde el punto de vista textual y codicológico" ".".

El autor citado ha acometido este estudio con toda la bibliografía anterior y el mismo texto a la vista, y tal estudio se completa con la monografía que desde el ángulo artístico le ha dedicado el Prof. Sicart. ".

Dejando a un lado aspectos codicológicos y ciñéndonos a las conclusiones paleográficas se afirma ahora que desde el punto de vista artístico se establecen para el códice unas relaciones con Castilla y Navarra y desde el punto de vista del contenido de Salmos y Cánticos, con el mundo de la Rioja y Castilla Oriental; si bien el autor, aunque formado en tierras burgalesas, pudo haber trabajadoras en León. "Todo ello me inclina a pensar -concluye Díaz- que acaso tendríamos que situar el origen de nuestro manuscrito en la región de Sahagún o quizá todavía más el Este... El carácter singular de este códice parece no permitir mayores aproximaciones».

El Libro de Horas fue escrito en el año 1055 por el escriba Pedro y fue su ilustrador el miniaturista Fructuoso.

El Libro de Reglas signado por Leodegundia. Este códice ha estudiado recientemente por el Prof. Díaz y en su monografía recoge la bibliografía existente con anterioridad ${ }^{36}$. El autor, después de analizar minuciosamente la composición y contenido del códice, se plantea los problemas del ¿dónde? y ¿cuando? de la copia del mismo, con razonamientos exhaustivos para ambos interrogantes. «Lo primero que sorprende a los estudiosos -dice Díaz- es la seguridad con que se le viene atribuyendo origen gallego». Desde Pérez Bayer y Eguren hasta Cotarelo y aun Millares, se han esforzado en probar la procedencia galaica del manuscrito, e incluso manifiesta éste último que tendríamos en él «el ejemplo seguro de la escritura usada a comienzos del s. X en el territorio gallego»". "Sería mejor decir el único», añade Díaz en sus comentarios.

Pero los datos de todos estos autores son, más que testimonios, conjeturas que buscan mutuas justificaciones. Y lo que decimos del lugar de la escritura -la Bobatella de la provincia de Lugo- se extiende a la fecha de la ejecución. El colofón del mismo, escrito por Leodegundia en el fol. $186 \mathrm{v}$., parece terminante al respecto: 0 vos omnes qui legeritis bunc codicem mementote :: clientula et exigua

"DíAz, Códices, p. 279. Para todo este apartado cf. las pp. 279-292.

"Angel SiCART, La miniatura, pp. 21-44.

"DíAz, Códices, mpp. 91-114.

"Millares, Los códices visigóticos de la Catedral toledana, Madrid, 193, pp. 74-

75.

${ }^{8}$ Díaz, Códices, p. 109. 
Leodegundia, qui bunc scripsi in monasterio Bobatella regnante Adefonso proncipe in era $D C C C L$...

Sin embargo, la fecha ha sido objeto de múltiples controversias y tanto los hechos históricos como los paleográficos desmienten esta data. Refieriéndose a estos últimos, y con las mayores cautelas, afirma el Prof. Díaz: «El tipográfico recuerda en numerosas ocasiones códices de región castellana oriental, con exclusión por supuesto, de los grandes escritorios de tendencias preciosistas en su caligrafía. En el decurso del códice hallamos ciertos rasgos orientadores: tal la presencia del bucle, arrancando del caído de la p, con amplio caracol, para marcar la sigla per... tal también el empleo de un trazo en forma de gamma invertida para señalar abreviación, que es típico de la escritura documental en pergaminos del siglo $\mathrm{X}$ en la región de León-Sahagún, sin que se pueda encontrar por esta época en otras zonas». Refiriéndose concretamente a la fecha de comienzos del siglo X para la copia, se basa en que "paleógrafos han visto la imposibilidad de suponer que el códice haya sido escrito en ningún caso antes del siglo $\mathrm{X}$, toda vez que la distinción $\mathrm{ti} / \mathrm{t}$ j se observa rigurosamente y de forma muy regular en todos los sectores y por parte de las diferentes manos que han intervenido en su copia»". "Así pues, -concluye Díaz- podemos resumir que el denominado "Códice de Leodegundia» producto de región leonesa en los comienzos del siglo $\mathrm{X}$ está en realidad integrado por restos de dos manuscritos diferentes aunque emparentados... y que a pesar del tono marcadamente femenino de parte de este manuscrito, todo parece señalar que estaba en uso en un centro masculino a fines del siglo $\mathrm{X}$ o comienzos del XI» ${ }^{40}$.

3.2.1.3. Colligere fragmenta... Pasemos de los buenos deseos a las realidades. Los archivos de nuestras Catedrales y de nuestros centros estatales han tratado de recoger cuanto de antiguo pudiese haber en las encuadernaciones de manuscritos más modernos que se custodian en los mismos. Resultado de esta paciente investigación son los fragmentos de códices visigóticos que actualmente podemos ofrecer, referidos a las catedrales de Santiago y Orense, al Museo de Pontevedra, y a los Archivos Históricos Provinciales de Orense, Lugo y Pontevedra, datables en una mínima parte en el s. X-XI, y en su mayoría en la época de transición de comienzos del siglo XII. A ellos se añade un fragmento conservado en Madrid, en la Sección de Códices del AHN, núm. 10444B, que puede datarse en la segunda mitad del siglo X; un fragmento conservado en la Sección de Varios del Archivo Regional de Galicia.

${ }^{39}$ Díaz, p. 111.

"Díaz, Códices, pp. 113-114.

"Esta es la relación de los fragmentos conservados y conocidos hasta el presente.

A) Santiago, Catedral. Fragmentos 1 y 2 . Dos folios sueltos pertenecientes a un mismo ejemplar de Misal romano con misas correspondientes a junio y julio. Miden actualmente $310 \times 230 \mathrm{~mm}$. y sirvieron de guarda para un Libro de Subsidios del año 1500 . 
En su casi totalidad corresponden a libros litúrgicos: misales, breviarios, leccionarios, Lier orationum y Misticum; más tres fragmento bíblicos y una Excerpta canonum.

El Misal fue copiado probablemente a comienzos del s. XII pero no necesariamente en escritorio compostelano. Posiblemente del mismo escritorio que el fragmento núm. 3 (DíAz, Códices, pp. 465-466, núm. 200).

Fragmento núm. 3. Distinto y probablemente anterior a los i y 2. Mide actualmente $305 \times 200 \mathrm{~mm}$. Se trata de un Breviario, de rito romano, con lecciones relativas al lunes de Cuaresma. Calidad de escritura aceptable, aunque no necesariamente escrito en Santiago. Sistema abreviativo típicamente carolino y quizá de finales del siglo XI. (Ibídem, p. 466, núm. 201).

B) ORENSE, Archivo Catedral. Manuscrito 13. Fragmento de dos folios de un mismo cuaternión, pergamino basto y poco raido, que recuerda el fragmento del mss. 20 del mismo archivo. Se trata de un Misal y su escritura podría situarse a finales del siglo XI, aunque Janini y Millares lo situan en el s. XII. (Ibidem, p. 439, núm. 168).

Manuscrito 20. Fragmento de dos folios, en pregamino basto y poco cutido. Contiene las lecciones de la fiesta de Santiago al 30 de diciembre. Es un Breviario. El conjunto está bien escrito, con letra de tendencias redondeadas, bastante bella; textos neumados con notación musical en campo abierto; pertenece a comienzos del s. XII, con sistema abreviativo típico de la fecha. (Ibidem, p. 440, núm. 170 y DURO PEÑA, Los manuscritos de la Catedral de Orense, p. 204).

Manuscrito 43. Fragmento cortado de un bifolio mutilado que mide actualmente 285 $\times 275 / 295 \mathrm{~mm}$. Fragmento utilizado para "Quentas de Mayordomos de la Mesa Capitular en el s. XVII. Contiene unos excerpta canonum (9.6,7-10,4.21), y los Capítulos 5 a 15 del Concilio de Nicea. Su letra es de singular nitidez, aparentemente de tipo leonés, quizá de los alrededores del propio León. Todo parece indicar que fue escrito a mediados del siglo $\mathrm{X}$ (Ibidem, pp. 440-1, núm. 171).

Manuscrito 44. Un folio recortado de una Biblia, que mide actualmente $365 \times 200$ mm. Contiene Ezequiel 30, 18-32.2. Mal conservada la escritura, los caracteres denuncian un escriba poco hábil pero concienzudo. No hay rasgos específicos que denuncien procedencia que puede ser gallega, en el s. XI (Ibidem, pp. 442, núm. 172).

Fragmentos de Xunqueira de Ambía. En 1964 el archivero de la Catedral de Orense, Duro Peña, localizó en la excolegiata de Xunqueira de Ambía una colección de documentos y algunos fragmentos de códices, que se depositaron en el Archivo Catedral. De ellos dos en escritura visigótica, que son dos folios incompletos del mismo códice bíblico. La letra es clara, de tendencia redondeada, de época de transición de la visigótica a la carolina, cuya huella se descubre en el sistema abreviativo. Podrían situarse hacia el maño 1100. DURO PEÑA supone que podría tratarse de los restos de una "Biblia de letra gothica», de la que habla Morales en su «Viaje Santo» (Ibidem, p. 442, núm. 175).

C) OREnSE. Archivo Histórico Provincial.

Fragmento 1. Cinco trozos conservados en la encuadernación de un apeo de los bienes de Santa Clara de Marmontelos, en Maceda de Trives. Los cinco corresponden a un Breviario Romano con utilización de neumas de acuerdo a las partes cantables. Las abreviaturas las normales de la época y su datación en el siglo XII. (Ibidem, p. 443, núm. 174).

Protocolos 287, 3428. Fragmento litúrgico utilizado en un protocolo de Fernán Pérez, 
La morfología de sus escrituras concuerda en todo con las de los códices conocidos en las mismas fechas en otras regiones occidentales.

En nuestra nota 41 doy una referencia pormenorizada de cada uno de estos fragmentos.

3.2.2. Los documentos. Información general. En el campo documental voy a referirme exclusivamente a los de carácter privado, porque son los que con toda seguridad han sido realizados en escritorios locales, si bien cabe la posibilidad de que alguno de los reales hay sido confeccionado también en escritorios gallegos.

Para mayor claridad expongo sumariamente la geografía actual e histórica de tales documentos. En la actualidad los tres centanares aproximadamente de documentos visigóticos que todavía pueden localizarse se encuentran en buena parte en la Sección de Clero del AHN, del que ya hemos hecho mención; un grupo muy importante se custodia en el archivo de la Catedral de Lugo, sección de Documentos sueltos; la de Orense, en su importantísima colección monacal, dispone de siete documentos visigóticos; y la Tuy dispone de otros cuatro ya tardíos, de los cuales dos son de los condes don Raimundo y doña Urraca; Santiago posee dos fondos de regular importancia: uno en el Archivo Diocesano, sección del monasterio de san Martín Pinario en número aproximado al medio centenar en no muy buen estado de conservación; y otro en el Archivo Histórico y Universitario, Pergaminos, fondo antiguo de san Martín P. La Coruña conserva en el A.R.G. unos pocos procedentes de variados lugares en la sección facticia de Diplomas; y algunos más se encuentran dispersos en archivos menores o localizaciones privadas.

de 1575, quizás de Orense. Contiene oraciones y fórmulas de fiestas del mes de agosto. La copia del manuscrito, un misal romano, puede situarse en la primera mitad del s. XII, con abreviaturas comunes en la época. (Ibídem, p. 447, núm. 175).

Protocolos 416, 3035. Fragmento de "Mistico» con fuerte influencia de la liturgia romana. Mide $305 \times 200 \mathrm{~mm}$. y procede de la encuadernación de un protocolo de san Esteban de Ribas de Sil, san Martín de Nogueira, del año 1619, por lo que podría conjeturarse que podría haber pertenecido al monasterio de Ribas de Sil; obra local o, al menos, de ambiente galaico, realizada probablemente a mediados del siglo XI, (Ibídem, p. 444, núm. 176).

Ribas de Sil. Jurisdicción de Pereiro de Aguiar. Protocolo de Gregorio de Porras, año 1620. Fragmento de Breviario, que contiene el oficio de un viernes y un domingo. Su escritura en cuanto a abreviaturas es ajena al sistema visigótico y el rubricador dibuja unas letras de estilo carolino, y otras del modo tradicional hispánico. Debe situarse a mediados del siglo XII (Ibidem, pp. 444-5, núm. 177).

Jurisdicción de Allariz. Protocolo de Andrés de Sandianes, año 1564. Fragmento de Leccionario, conteniendo I Cor. 5,3 y ss. Pergamino basto, insuficientemente raido. Se conserva un folio y medio más con medidas actuales de $475 \times 300 \mathrm{~mm}$. y $230 \times 235 \mathrm{~mm}$. La 
El reparto geográfico-histórico comporta el problema de los posibles escritorios visigóticos, que me parece de interés para establecer áreas culturales. Gráficamente expongo la situación en el mapa que acompaña como material gráfico a esta exposición ${ }^{42}$.

a) Área compostelana. Probablemente de ascendencia real, de origen monástico, abarca, según la documentación conservada, los monasterios de San Payo Antealtares, san Martín Pinario y la Catedral, aunque ésta no esté representada en la documentación actual. De este centro principal serían derivaciones los documentos procedentes de Iria, los de tierra de Salnés y los pocos y dispersos que todavía pueden verse de la región trastamárica de la diócesis compostelana. Entre ellos mencionaré los ejemplares procedentes de Montesacro, vecino a Santiago, un documento procedente de san Xoan da Cova

letra es interesante, de transición, muy influida por el sistema abreviativo carolino. La fecha probable es la de comienzos del siglo XII (Ibídem, p. 445, núm. 178).

D) La Coruña. Archivo Regional de Galicia. Sección de Varios. Fragmentos de códices. Folio procedente de un Leccionario, $300 \times 210 \mathrm{~mm}$. en su estado actual. Escritura visigótica de comienzos del s. XII con bastantes rasgos carolinos: et, aut, -autem, letras sobrepuestas, etc. Procedente de una Ejecutoria de bienes de la Coruña, quizá procedente de una iglesia o monasterio de la zona Norte de la diócesis de Santiago. Su datación en el siglo XII. (Ibidem, p. 388, núm. 95).

E) Lugo, Archivo Histórico Provincial. Fragmentos biblicos. Dos fragmentos de un mismo manuscrito, recuperado de la encuadernación de un protocolo notarial del siglo XVI. Parecen restos de una gran Biblia del s. XI y, aunque no hay noticia de su procedencia, parece que pueden ser de la misma ciudad o su zona de influencia. (Ibídem, Códices, pp. 405-407, núm. 127).

F) MADRID, Archivo Histórico Nacional. Códices 1044 B (83). Fragmento de un tercio de folio $(142 \times 238 \mathrm{~mm}$., recortado por todos lados, que sirve de guarda de la tapa posterior del Tumbo de san Salvador de Villanueva de Lorenzana. Todo parece indicar que fue copiado en la segunda mitad del siglo X, como parte de un códice biblico. Nada se opone a que el fragmento y su original procedan de monasterio de Lorenzana, aunque Díaz encuentra en él influencias leoneses, o incluso de la Rioja. (Ibidem, p. 412, núm. 137).

G) PONTEVEDRA, Museo Provincial. Parte de un folio cuyo anverso está totalmente ilegible + PONTEVEDRA, AHP. Pertenecen a un sólo manuscrito de la Colección Hispana, en cuaterniones diferentes. Escritura leonesa de la segunda mitad del siglo X, Proviene probablemente de algún centro en el Salnés.

H) Pontevedra, Archivo Histórico Provincial. 1. Bifolio de un breviario con antífonas anotadas. Proveniencia probable análoga al anterior. Siglo XII.

2. Restos de varios folios de un Antifonario. Siglos XI-XII, de origen probablemente gallego.

3. Restos de cuatro folios de otro Antifonario. Siglo XI avanzado.

Las noticias referentes a estos manuscritos de Pontevedra las debo a la amabilidad de mi compañero, el Prof. Manuel Díaz, que ha tenido la astención de comunicármelas, antes de que sean estudiadas por él y Publicadas. Mi agradecimiento sincero por esta deferencia.

${ }^{42}$ Cf. en Material gráfico, la Escritura visigótica en Galicia. 
en el Ulla, hoy en el archivo parroquial de Santa María de Sar, y los restos que nos quedan de los monasterios de Almerezo, Soandres y Moraime en tierra de Bergantiños.

El monasterio de Cinis, próximo a la región de las Mariñas de Betanzos, es fundación probable de san Payo de Antealtares y de aquí llevaría las muestras de escritura que reflejan los documentos conservados.

Quizá podría extender la zona de influencia del área compostelana al monasterio de santa María de Sobrado, teniendo en cuenta la intervención que en él tuvieron los condes Hermenegildo y Paterna y el obispo Sisnando, educado en la escuela episcopal compostelana. Pero los documetos que nos quedan son tardíos y representan un estadio nuevo en el que se produçirá un cambio radical con su adscripción al Císter.

b) Área lucense-samonenese. La segunda área a considerar es la de la iglesia de Lugo con la que está en íntima conexión el monasterio de Samos. Área extraordinariamente rica en documentos conservados y de gran variedad morfológica; en algunos casos podemos asegurar que ambos centros tienen evolución propia y tanto unos como otros son un buen exponente de las grafías visigóticas gallegas. A este área habría que adscribir los escasos testimonios procedentes de las actuales parroquias de Mao, Penamayor, Barbadelo y Devesa.

c) Área de Carboeiro. Instalado este monasterio entre las dos áreas anteriores, es de menor importancia su aportación y participa, quizá, de las corrientes de las áreas compostelana y lucense. Tuvo luego, a mi parecer, una evolución propia e influyó, sin duda, en los pequeños centros monásticos o decanías de la Castella ribadaviense, de la provincia de Orense, entre los ríos Miño, Avia y Oviniano.

d) Área de Oseira. Aunque de fundación tardía y sin entorno conocido, conserva el monasterio de Oseira una buena colección de documentos visigóticos -35 en total-, que lo situan como centro propio de producción documental.

e) Área de Celanova. En la provincia de Orense, este monasterio representa la unidad más importante de la época visigótica a juzgar por la cantidad y calidad de los documentos del mismo conservados en su Tumbo. Pero la escasa representación gráfica visigótica -un sólo documento-, hacen imposible la calificación de esta área.

f) Centros menores. Para agotar las posibilidades, citaré otros centros en los que pudo haber actividad escriptoria en esta época: Lérez, Armenteira, en la provincia de Pontevedra, de los que poseemos escasas referencias; Ribas del Sil en Orense, y Caaveiro en la provincia coruñesa, con muy mermada representación gráfica.

${ }^{43}$ DíAz, Códices, pág. 466, nota 360. 
3.2.2.1. La periodización morfológica. Me parece innecesario entrar en el problema de los orígenes de la escritura visigótica ya repetidamente debatido y resuelto. Como observación personal puedo decir que nuestra visigótica primera, especialmente la del área Lugo-Samos, puede ofrecer documentos que claramente enlazan con las tradiciones de la minúscula romana de siglos anteriores, constatada en otros lugares del imperio romano.

Morfológicamente la escritura documental visigótica de Galicia se desarrolla en tres fases sucesivas:

Una primera de claro predominio de las formas cursivas tradicionales y similares a las otras áreas y lugares de los reinos occidentales de la Península, con manifestaciones rurales repetidas, como las del documento de la catedral de Lugo del año 973 y que representan, a mi juicio, testimonios aislados de una escritura realizada en medios no urbanos, por persona no profesional y avezada, que imita en su trazado los modelos de los libros litúrgicos que tiene a mano, sobre una estructura inicial mal aprendida asimilada en la escuela episcopal o monástica.

En una segunda fase, alternan escrituras cursivas y caligráficas, aunque predominen aquéllas, y se obtiene un tipo de escritura ligera, semicaligrafiada, o mejor semicursiva, en la que cabría ver influencias de una corriente leonesa procedente del monasterio de Sahagún y de otros escritorios ligados a la realeza imperante. Quizá, haya que considerar aquí nuevas formas en el corte de la pluma y más soltura en el trazado y enlaces de las letras, que dan origen a formas singulares de gran belleza. No me parece necesario, aunque sí conveniente, insistir en el hecho de que tal escritura -tanto la de Galicia como las foráneas- estaría relacionada con las formas alargadas y artificiosas que se producen en torno a las cancillerías provinciales de la baja romanidad y que tuvieron su consecuencia en la letra de cancillería merovíngica y también, a no dudarlo, en algunos momentos de la leonesa, especialmente desde la segunda mitad del s. X.

En una tercera fase situo el decrecimiento de la cursiva, para dar cabida a la escritura caligráfica, concretamente de imitación castellana, en los escritorios tanto urbanos como rurales. En esta fase se pueden distinguir dos momentos importantes: uno en el que la innovación de la escritura coincide con un sistema abreviativo totalmente visigótico; y otro en el que la escritura va acompañada de un sistema abreviativo que cae bajo las influencias de la importada escritura carolina, e incluso la estructura de las letras padece la influencia estructural de una minúscula carolina en decadencia en Europa y que se nos muestra rígida y rectilínea.

Una variante cronológica en el desarrollo de esta tercera fase puede apreciarse en el escritorio de Compostela, en donde las circunstancias son diferentes a las de cualquier otra área. La situación de Compostela a comienzos 
del siglo XII, fuertemente influida por maestros, monjes y artistas venidos de Francia, o regiones muy marcadas por los ambientes cluniacenses, parece excluir una pervivencia residual de la escritura visigótica, aunque se la suponga fuertemente impregnada de carolinismos. «Santiago, a mi entender -dice Díaz-, se convierte desde el último cuarto del siglo XI en un baluarte y puesto avanzado, tanto de las corrientes francesas, alentadas por Cluny y favorecidas por el intercambio de los peregrinos, como de la liturgia romana. Todo el culto jacobeo, como señala el Códice Calixitino, a diferencia de lo que se observa en los códices litúrgicos visigóticos, se desarrolla en rito romano, con inusitado esplendor. No resulta, pues, satisfactorio pensar que en escriptorio compostelano se ejecutaran estos productos gráficos que, pese a las innovaciones, no pasan de ser manuscritos de la vieja letra con adaptaciones y adobos de la nueva escritura». Estas palabras, suscritas para los códices, pueden aplicarse perfectamente a los documentos, como tendré ocasión de señalar más adelante.

3.2.2.1.1. Littere antiquae. Dejo para luego y como anécdota el comentario sobre el supuesto documento más antiguo de los existentes en Galicia, y denomino con este nombre a los ejemplares documentales que pueden encontrarse entre nosotros entre los siglos VIII y X, recogidos fundamentalmente en el área lucense-samonense. En él se incluyen algunos documentos, cuya fecha pertenece a los siglos mencionados, pero cuya estructura gráfica los aleja sensiblemente de este período, y ello como muestra de cómo el análisis de la escritura puede ayudarnos a una calificación original/copia de los documentos analizados. Entre los documentos que quiero mostrar individualmente destaco una donación de Alvito a la iglesia de Lugo del año 745 y el famoso segundo testamento de Odoario. El primero es una clara copia del s. XIII de transición a la carolina y no anterior en su copia al año 1150; y el segundo,a juzgar por sus características gráficas, ha de traerse a la segunda mitad del s. XI, comparable con un documento de la misma catedral lucense de los años 1068-1070.

También de la catedral de Lugo es el documento del año 837, pero con una escritura del s. XII primera mitad y de claras influencias carolinas.

Del monasterio de Samos es un documento del año 818 escrito seguramente y recopiado en caligráfica visigótica del s. XII; y del monasterio de Almerezo, en la Coruña, un documento del año 867, que podría pasar como original, si el sistema abreviativo no le denunciase como de influencia compostelana del siglo XI final.

Dos más del monasterio de Carboeiro: uno del año 878, tiene una tendencia a la caligrafía que se observa en este cenobio a final del siglo XI; y del otro cabe decir que no sólo no es original, sino que ni siquiera pertenece a Carboeiro, sino que procede de un escritorio de ambiente compostelano de la segunda mitad del siglo XI. 
Excluidos de la serie estos documentos, quedan como posibles primeros candidatos a la denominación un documento de la catedral de Lugo del año 861 , del que, si se admite su originalidad, habría que hablar más bien de una coetaneidad de la copia, ya que la escritura que ostenta se refleja un siglo más tarde en dicho centro.

Creo que se puede hablar, con toda seguridad, de productos de «littera antiqua» en unos documentos de Samos, datados en 905, al que seguiría alguno de san Martín Pinario de Santiago, y una buena cantidad de varios escritorios, todos ellos datables en el s. $\mathrm{X}^{* 1}$.

3.2.2.1.2. El siglo XI. La segunda fase morfológica coincide con el siglo en su casi totalidad. Son muchos los documentos que representan esta fase, con variantes puramente accidentales, que dependen de la mayor o menor agilidad del amanuense y que se caracterizan por una concesión, más o menos amplia, a la altura, la anchura, redondez o grosor de la letra, pero siempre dentro de un canon cursivo y de rápido trazado. Podrían analizarse subtipos de esta escritura, teniendo en cuenta las características antes señaladas, pero quedaría fuera de nuestro propósito actual.

3.2.2.1.3. La transición caligráfica y la influencia carolina. La última fase morfológica tiene una cronología que se extiende desde el último tercio del siglo XI hasta la terminación en cada caso de la escritura visigótica, fase que puede situarse, en términos medios, a la mitad del s. XII.

Esta fase se subdivide en dos momentos: el primero con inicio en los últimos decenios del $\mathrm{s}$. XI, que es la del tránsito de las formas cursivas a las caligráficas de imitación codicológica castellana, con claras hibridaciones del sistema abreviativo cursivo; y el otro, que comienza en el segundo tercio del s. XII aproximadamente y termina en tiempo variado, y que se caracteriza por unas realizaciones básicamente caligráficas, pero con influencia creciente de carolinismo en el sistema abreviativo y en el mismo tratamiento de la escritura.

Cuantitativamente puede fijarse la evolución de esta escritura en la fase que comento en las siguientes curvas de frecuencia: proporción 2 a 1 para la documentación visigótica durante los primeros decenios de la transición; un igualamiento en el uso de la antigua y de la nueva forma a mediados del s. XII; y una proporción de 2 a 1 para la letra carolina en la segunda mitad del siglo, proporción que, como es lógico, se hace más favorable a las nuevas formas a medida que avanzan los últimos decenios del siglo.

De estas frecuencias se excluye, como antes he dicho, el escritorio compostelano, donde la transición es rápida y puede considerarse efectuada al terminar

14 Para éste y los siguientes apartados, cf. en Material gráfico: «Comentarios de especímenes visigóticos" y "Rcproducciones de documentos». 
el tercer decenio del siglo. Como ejemplo de ello puede valernos el documento de la fundación del monasterio de Sar, dado en el año 1136 y redactado en una preciosa letra carolina, en la que sólo destacan como signos visigóticos las suscripciones de algunos personajes, canónigos de la Iglesia compostelana, gentes de edad, que siguen aferradas a sus viejas tradiciones ${ }^{45}$. Otro ejemplo podría ser el del documento 1159, conservado entre los de Meira del AHN, pero procedente del escritorio compostelano, y con unas características semejantes a las del anterior ${ }^{40}$.

3.2.2.1.4. Los "antiquissima". Como colofón anecdótico a este ya largo apartado traigo a colación el documento considerado más antiguo de Galicia. Se trata de la venta que en el año 788 realiza una tal Quiza Gonteriquiz a un Cakaril y otros de una vila por precio de siete vacas. El documento, que se conserva entre los del monasterio de Carboeiro en el fondo de San Martín Pinario, del archivo universitario, ha sido repetidamente estudiado y discutido, tanto en sus formas gráficas como en su estructura diplomática por múltiples investigadores, con criterios varios que van desde el entusiasmo de López Ferreiro, quien trató de fundamentar sobre él y sus suscripciones la existencia de una Galicia reino independiente en la región del Deza de la montaña pontevedresa, hasta el hipercriticismo de Martínez Salazar.

Me ocupé de él en un trabajo sobre el monasterio de Carboeiro ${ }^{47} \mathrm{y}$, consideraciones diplomáticas aparte, porque no son ahora del caso, el análisis paleográfico y su comparación con otros textos del mismo monasterio me ha llevado a la conclusión de que tal documento -auténtico o no- ha sido elaborado en su forma actual no antes del comienzo del siglo XII y es comparable a otros documentos del mismo centro, situados entre los años 1100 y 1119. Estas observaciones distan bastante de las de López Ferreiro, que llevado de su entusiasmo nacionalista comparó sus grafías nada menos que con las del documento del rey Silo de la Catedral de León; comparación imposible, porque pertenecen a dos mundos gráficamente distintos: urbano y de círculo real el uno; y netamente rural el otro, en manos de un escriba nada habituado a las tareas de la escritura ${ }^{48}$.

3.2.2.1.5. Los «novissima». Por la misma razón me detendré en la

45 Privilegios reales, núm. 2; y Material gráfico, 3.3.3.1., núm. 1.

${ }^{46}$ M. LUCAS ÁlVAREZ, En torno a un documento atribuido al monasterio de Meira, CEG, XXII (1952), p. 353-369.

${ }^{47} \mathrm{M}$. LuCAs Álvarez, La Colección Diplomática del monasterio de Carboeiro, esp. pp. 235-38 y bibliografía citada allí.

${ }^{48}$ Cof. la reproducción en Material gráfico, Reproducción de documentos, núm. 1. 
consideración del documento que Martínez Salazar ha denominado como el último representante".

Se trata de un documento del año 1234 , perteneciente al monasterio de Almerezo, en la comarca bergantiñán, alejado de contactos culturales. Tiene caracteres de originalidad y muestra una escritura caligráfica con fuertes influencias del sistema abreviativo carolino, que admite una comparación con originales datados cincuenta años atrás. Ahora bien, este documento no debe distorsionar nuestra visión de la pervivencia de la visigótica en Galicia, como un signo de conservadurismo de las formas gráficas, ya que al lado de él, que es una auténtica excepción, tenemos una ingente cantidad de documentos que reproducen la minúscula diplomática imperante en la totalidad del territorio.

Creo que las cifras pueden quedar establecidas así: en San Martín de Santiago hay sólo dos documentos posteriores a 1150; Carboeiro tiene cuatro posteriores a esta fecha, uno de ellos de 1199; Sobrado conserva seis posteriores a dicha data, uno de 1194; Lugo sólo dos de 1152 y 1156 ; Samos uno de 1191; Penamayor uno de 1164; Melón tres de 1152, 1159 y 1165; Meira cuatro entre 1150 y 1163; en la Catedral de Orense hay uno de 1176; Oseira, ocho datados entre 1150 y 1189 . En total, unos cuarenta documentos en visigótica que sobrepasan el año 1150 y frente a ellos muchos centenares de la misma época escritos en minúscula carolina o en la extendida minúscula diplomática en sus distintas variantes, lo que confirma las curvas de frecuencia a la que antes me he referido.

\subsection{El amplio ciclo carolino. (Siglos XII-XIII ${ }^{2}$ )}

Con esta denominación quiero abarcar toda la actividad escriptoria que se realiza entre nosotros desde el momento en que se lleva a cabo el cambio de escritura, tal como está diseñado anteriormente (apartado 3.2.2.1.3), hasta que definitivamente se implantan los criterios de las escritura gótica.

Es de todos conocido el acontecimiento de la implantación tardía de la carolina en el occidente hispano y ello ha determinado el tipo y calidad de escritura que aquí se transfiere. Hemos heredado una carolina a punto de transformación en Europa, donde ya se la denominaba «minúscula del s. XII» o incluso "postcarolina». Nuestros códices gallegos escritos en este período se mueven en esas coordenadas cronológicas y gráficas, e incluso alguno tan temprano como la primera parte del Tumbo A de la catedral de Santiago, escrito en el año 1129, acusa ya los formalismos y tendencias de una escritura gótica incipiente.

En el campo documental incluyo en este período las variantes de la llamada minúscula diplomática, denominación escurridiza en ocasiones, que

49 Andrés MARTÍNEZ SALAZAR, Diplomática gallega. ¿el último representante de la escritura visigoda?, BRAG, VIII (1913), p. 49-56, con 1 lámina que reproduce el documento. 
pretende recoger los movimientos de la escritura carolina y su desplazamiento hacia las primeras formas de fractura, que han de caracterizar luego a la gótica documental.

En los reinos occidentales estas manifestaciones empiezan a producirse en la segunda mitad del siglo XII y pueden considerarse terminadas en el siglo XIII, primera mitad. Entre nosotros los hechos suceden aproximadamente en las mismas fechas; y el posible retraso puede ser imputable al conservadurismo gallego, que no impide la introducción de novedades.

Dentro de este cuadro general analizaré las variantes; y en primer lugar algunas palabras sobre los centros de producción de escrituras.

3.3.1. El «Scriptorium* de Compostela. A decir verdad, no es sólo Compostela la que dispone de un "scriptorium» y escuela de formación. Las producciones codicológicas y aun documentales del período nos hablan claramente de que debieron existir bastantes centros de escritura, pero nuestras noticias sólo alcanzan al compostelano. Ya hemos visto la penuria de datos existente sobre la escuela episcopal compostelana en la época anterior. A partir del s. XII la incógnita se despeja y, aparte del testimonio documentado del conde Raimundo, del que ya hice mención, puede añadir otro de la Compostelana en el que dice que Gelmírez había sido introducido en letras en la iglesia de Santiago y educado en la Curia del Obispo so.

En torno al clérigo y después obispo Diego Gelmírez debió girar a lo largo de la primera mitad del s. XII el esplendor de esta Escuela, y fueron luego sus sucesores en el episcopado, educador asimismo en Compostela, los continuadores de su obra a lo largo del $\mathrm{s}$. XII ${ }^{2}$ y del siglo XIII.

Una vez más la Historia Compostelana nos habla de cómo Gelmírez, para organizar una escuela rudimentaria en Santiago, pagaba de su peculio un profesor de elocuencia y lógica y, aunque la noticia puede ser apologística, para ensalzar las cualidades del Prelado, tiene importancia como testimonio. Y digo apologética, porque aparentemente hay una contradicción entre dos pasajes de la Compostelana, en uno de los cuales se dice que en tiempos de Alfonso VI el obispo Diego Peláez «constituyó veinticuatro canónigos absolutamente ignorantes del oficio eclesiástico»; y en el otro se asegura que Gelmírez "puso al servicio perpetuo de la iglesia setenta y dos canónigos instruidos en el conocimiento de las letras, peritos en el oficio eclesiástico». Ni tan ignorantes, quizá, los primeros, ni tan sabios los segundos; pues si no, ¿cómo explicarnos que en tan corto espacio de tiempo se hubiese consolidado tan firmemente una escuela capitular que fue capaz de producir tantos sabios?

Supone Díaz que la escuela de Santiago a mediados del siglo XIII tenía una

51) DíAz, Problemas de la cultura y LóPEZ FERREIRO, HIC, II-IV, para cuanto se refiere a este apartado. 
«muy desarrollada clase de aprendizaje de Latín» y combina para ello dos noticias, una de la Compostelana y la otra del Códice Calixtino. Cuando en 1136, en una de tantas revueltas de los burgueses compostelanos, huye Gelmírez por una de las puertas próximas a la Catedral, no se hace especial mención del nombre de esa puerta; pero cuatro años más tarde, en 1140, cuando el Códice Calixtino describe la fábrica de la Catedral dice a propósito de las mismas puertas, que la séptima es de grammaticorum schola, qui domo etiam archiepiscpi praebet ingressum; lo que quiere decir que para estas fechas tenía la tal escuela la entidad suficiente, como para destacarse con nombre propio ".

Por último, en dos disposiciones capitulares, una del 30 de julio de 1169 , que se conserva en el Tumbo B de la Catedral, fol. 143 v., y en el Libro de las Constituciones antiguas; y en otro documento de 25 de julio de 1170 , se afirma en la primera que aquellos clérigos de coro que tengan que ausentarse por razones de estudio, pueden percibir una parte igual a la que reciben todos de los dineros que se ofrecen en el Altar del señor Santiago, y ello «porque hay muchos -dice el acta- que, aunque abrigan sinceramente el propósito de estudiar, oprimidos con el peso de la pobreza, se ven imposibilitados de hacer lo que anhelan..."

El otro testimonio se refiere a la obligación que impone el Cabildo compostelano al Maestrescuela del mismo, de que debe poner un preceptor que enseñe Gramática, no sólo a los clérigos y niños del Coro de la Catedral, sino también a los de la ciudad y a los de la Diócesis et qui ad nutum magistri scholarum omnes litteras capituli dirigat et componat, o sea, que redacte y supervise las cartas que el Cabildo haya de enviar o escribir".

Los resultados de esta política cultural están a la vista. A Gelmírez se debe el primer lote conocido de libros que inaugura el tesoro de la Catedral, y entre ellos la colección canónica más autorizada en sus días, la Collectio in LXXIV títulos digesta, llamada comunmente Diversorum Patrum sententiae. De Santiago son una buena parte de los notarios que redactan los documentos reales del siglo XII en su primera mitad; aquí se instituye por vez primera la función cancilleresca; y aquí, hacia el final del siglo, comienza a tomar cuerpo la institución de los notarii iurati y del concejo, claro antecedente de la posterior institución notarial y a un siglo de distancia, en 1226, Compostela dispone de una biblioteca catedralicia de 93 libros catalogados e identificados ${ }^{34}$.

" DÍAZ, Ibidem, p. 192.

32 A. LÓpez FerReiro, HIC, IV, p. 292.

\$.3 Ibidem, p. 295 y apéndice XIII, Constituciones, I, fol. 3.

s4 Cf. infra apartado 3.5.3.1., add. Cf. José GARCía ORO, Un nuevo testigo, pp. 340-341, para los datos referentes a los libros de la biblioteca catedralicia de Gelmírez, y la de 1226 y también, H. OMONI, Catalogue de la Bibliothèque de Bernard II, archévêque de Saint-Jacques-de-Compostelle, 1226 en BECh., 54 (1893), pp. 327-333, que recoge la noticia 
3.3.2. Las producciones codicológicas. Los antecedentes que acabo de exponer referidos a Santiago, y otros no conocidos, pero sí intuidos de otros escriptorios, nos debían hacer concebir la esperanza de grandes realizaciones codicológicas, que no abonan los datos que poseemos.

La obra más importante de este período es el Tumbo A de la Catedral de Santiago, manuscrito realizado en virtud de un programa dispuesto por el canónigo y tesorero del Cabildo y colaborador del Arzobispo, don Bernardo. La obra, comenzaba en 1129 y que, en principio, debía constar de cinco volúmenes y recoger la documentación catedralicia procedente de reyes, pontifices, obispos, canónigos y particulares relacionados con la Institución, se quedó en el primero de ellos, dedicado a los documentos reales. En su estructura actual sólo los 62 primeros folios recogen la primera factura, que se completará más tarde en sucesivas etapas. Esta primera parte en lo artístico coincide con la miniatura románica, y en lo paleográfico con una escritura carolina de buena factura, con una dinámica morfológica y braquigráfica semejante a la de otros códices de la época".

La otra obra realizada y copiada en Santiago durante el pontificado de Gelmírez en los primeros decenios del siglo XII fue, sin duda, la Historia Compostelana, biografía apologística del pontificado de aquel Prelado, escrita por sus colaboradores y admiradores. Sin embargo, no disponemos actualmente del que pudo ser el ejemplar original, y sólo de una copia realizada en el siglo XIV, que comentaré más adelante.

De otros centros de Galicia no tenemos información precisa, si bien hay que tener en cuenta la actividad no pequeña y de baja calidad que reflejan los Tumbos y Cartularios que nos han quedado de esta época. Entre la segunda mitad del s. XII y la primera mitad del XIII, en esa época imprecisa de la transición al gótico se escriben entre otros: el Tumbo de Samos, en el año 1200; el de Celanova en la segunda mitad del siglo XII; y los de Caaveiro, Xubia, Toxosoutos, Lourenzá y el Tumbo viejo de la Catedral de Lugo, en el XIII, aparte de un Libro de Aniversarios conservado en la misma Catedral de Lugo; algunos folios más del Tumbo $A$ que coinciden con los reinados de Fernando II y Alfonso IX, y alguno de los códices y fragmentos que más adelante recogeré de la Catedral de Orense. (Cf. lams. 332/1 y 2) del Material gráfico ${ }^{36}$.

del Mss. 4 de la Biblioteca Municipal de Marsella, fol. 227 r.- La noticia ha sido dada a conocer por A. GARCÍA Y GARCÍA, La canonistica medieval en Galicia, Santiago, 1981, (Colectanea Scientifica Compostellana, 1), nota 7., recogido por J. GARCÍA Oro en Un nuevo testigo, p. 341, nota 9.

"La fama de est eTumbo, aparte de su contenido diplomático, es debida a la preciosa colección de miniaturas que preceden a cada uno de los grupos de domentos con la efigie del rey respectivo. Un buen estudios de los aspectos artísticos en SICART, A., La miniatura, p. 46-71.

"El Tumbo de Samos será editado en breve por LuCAs Álvarez, M.; del Tumbo de 
Mención especial merecen otros tres códices de esta época: uno el Complutense de la B. N. de Madrid, 1358, escrito en los años finales del siglo XII. Perteneció este códice al Colegio Mayor san Ildefonso de Alcalá de Henares y de allí pasó a la biblioteca real de Felipe V. Consta de 74 folios escritos en letra carolina que contienen un índice de las ciudades o sedes episcopales de España durante la época visigoda; prosigue con los Anales, que Flórez llamó Compostelanos, que llegan hasta el año 1143; otros varios tratados; y concluye con el Cronicon iriense y el diploma del Voto de Santiago. El códice fue escrito en esa ciudad como indica el colofón del mismo: «Ego Petrus Martirius, Dei gratia ecclesie beati Iacobi cardinalis, sicut inveni in alio loco scripto, quod in beati Iacobi thesauro et in eius tumio permanet, ita scripsi et hoc translatum et proprio robore confirmo".

El segundo es el Corpus Pelagianum, actualmente en la B. N. de Madrid con el núm. 2805, copia fiel del manuscrito Complutense, elaborado muy poco después del original, al que sigue íntegramente. Consta de 92 folios. De su calidad dice Sicart: «se aprecia una calidad muy superior a la del Códice Complutense, dando la impresión de que sus ejecutores eran auténticos profesionales en el oficio, los cuales también llevarían a cabo su labor en tierras gallegas" ".

Por último, el tercero de los códices es el Codex Calixtinus, conservado en el archivo catedralicio de Compostela, aunque de origen cierto francés, si bien se duda sobre el lugar posible de origen. Uno de sus autores, si no copista fue Aymerico Picaud, clérigo de Parthenay-le-Vieux ${ }^{58}$.

3.3.3. La producción documental. En el apartado 3.2.2.1.3. he indicado la incidencia de la escritura carolina en el sistema abreviativo y estructural de la visigótica en el s. XIII, así como la importancia del scriptorium de Compostela en la adopción de nuevas formas gráficas. Conviene ahora completar aquellas afirmaciones con el desarrollo que a lo largo del tiempo que he asignado a este ciclo se observa en el campo de los documentos, aspecto al que se refieren los apartados que siguen.

3.3.3.1. La carolina "stricto sensu». A partir del texto de 1136, del que he hablado anteriormente y a lo largo de la segunda mitad del siglo XII, y aún en el siglo XIII, vemos repetidamente en la documentación monástica unos

Toxosoutos hay una buena monografía en su aspecto artístico en SICARTART, A., La miniatura, págs. 111-128, con algunas precisiones paleográficas; y el Tumbo de Sobrado ha sido editado por Pilar LOSCERTALES en 1976 (Cf. Bibliografía). Los restantes han sido objeto de monografías especiales que, en muchos casos. permanecen inéditas.

"A. SICART, La miniatura, pp. 88-95, buenos estudios de ambos códices con ampliación de la bibliografía anterior.

${ }^{58}$ La bibliografía, muy abundante, de este códice y un estudio de sus miniaturas, en A. SICART; La miniatura, pp. 64-88. 
modelos de escritura que responden al canon más puro de la escritura carolina del s. XII en su vertiente codicológica: letras regulares, de tendencia a la redondez; distribución armónica de gruesos y perfiles; astiles y caídos de poca altura y prolongación, espacios regulares y abreviaturas comunes al ciclo. Dan la impresión de haber sido trazados por escribas profesionales de los «scriptoria», habituados a la copia de libros más que a la de documentos y que trasladan a éstos, a veces intrascendentes, la técnica de los grandes libros litúrgicos o de espiritualidad.

Pongo como ejemplos de esta pervivencia unos cuantos ejemplares en las láminas 3.3.3.1/ 1 a 5 .

3.3.3.1.2. Las escrituras minúsculas diplomáticas. Al lado de la anterior, coincidente con ella en cronología y superándola en el tiempo, se nos muestra la minúscula de ciclo carolino que venimos denominando «minúscula diplomática». En nuestra documentación tiene un eco amplio en los documentos del s. XII en su segunda mitad y a lo largo de la primera mitad del siglo XIII.

Sus textos ofrecen un panorama relativamente constante. Es una letra esbelta, de astiles y caídos largos y curvados; letra $d$ con frecuencia de tipo uncial ligeramente recurvada; letras aisladas y exentas de nexos; hay una ligera tendencia a la movilidad de los astiles a medida que avanza el período; letra $g$ muy generosa en la curvatura de su parte inferior; tendencia generalizada a incrementar la fractura interna de los cuerpos de las letras y abreviaturas muy frecuentes pero comunes en el período.

No es necesario señalar otros caracteres especiales y de ella doy unas muestras en las láminas que ilustran la parte gráfica en las láminas 3.3.3.2/ 1 a 9 .

El aparente equilibrio de esta escritura se quiebra en manos de los escribas profesionales. Lo he observado en el escritorio compostelano a partir de los últimos años del siglo XII, con un amanuense llamado Lope Arias, titulado Iuratus del concejo de Santiago; y después de él en otros muchos escribas y notarios de la región, especialmente en el siglo XIII, a medida que estos iurati y otros profesionales se convierten en notarii reales o de los obispos, monasterios y señores, en virtud de las nuevas disposiciones legislativas, o de los usos ultrapirenaicos.

Su escritura es rápida, quebrada; se aprecia una tendencia a la separación de los caracteres constitutivos de cada cuerpo de letra; se incrementan los movimientos ondulatorios de astiles y caidos; comienza el uso de una $s$ redonda en los finales de palabra; y se acentúa progresivamente el apuntamiento de los rasgos verticales y de los curvos, sin llegar al goticismo tradicional. Sus formas son muy variadas y en casos, como el del escriba del monasterio de Ramirás, Petrus, que tuvo larga permanencia en aquel monasterio femenino (cf. láminas 15-16 y 21-22), puede apreciarse el deterioro de la escritura que se va produciendo con el paso de los años y el envejecimiento del escriba. 
Los ejemplos que ilustran este apartado creo que son suficientemente precisos para observar este género de escritura al que denomino «minúscula diplomática currens o cursiva» (Cf. láminas 3.3.3.2/10 a 22).

En ocasiones, cabría hablar de la cursiva, cuando los astiles se curvan sobre sí mismos hasta rematar en bucles cerrados, o las $d$ se cierran en un lazo total y el conjunto ofrece un despiece claro de las estructuras de sus letras y un trazado rápido. (Un ejemplo de este tipo de escritura en la lámina 3.3.3.2./23).

\subsection{El Ciclo Gótico}

Este ciclo está reconocido por todos los paleógrafos y no voy a repetir lo que es sabido de todos. Galicia se incorpora a él en unas fechas que coinciden sensiblemente con las de los reinos occidentales de la Península, y si en ésta se ha señalado la segunda mitad del siglo XIII como la del comienzo de la etapa de madurez de lo gótico, en Galicia, con los datos que tenemos a la vista, puede seguirse la misma datación cronológica e incluso adelantarla un tanto. Examinaré seguidamente la situación de la Escuela compostelana como continuación y planteamiento del sistema productor de escrituras; a continuación la producción codicológica de la época y, seguidamente, la producción documental con un análisis previo de los factores que hayan podido influir en el desarrollo de la escritura en este período y su morfoligía. Lo mismo que decimos de lo paleográfico, podemos señalarlo también para las consideraciones artísticas de los códices".

3.4.1. La escuela compostelana en torno al arzobispo don Berenguel de Landoria. En un estudio reciente se ha hecho el análisis de la labor cultural de este polémico Arzobispo compostelano ${ }^{60}$. Discutido, emprendedor e innovador, trajo a su diócesis nuevas inquietudes y trató de poner orden, tanto en la administración espiritual de su diócesis y temporal de su ciudad, como en la cultura. «La iniciativa legislativa -dicen los autores de la mencionada monografía - tuvo un meritorio complemento en la organización archivística que le acompañó y siguió y cuyo producto son los Tumbos B y C, y el Libro segundo de las Constituciones que hoy conserva el Archivo Catedralicio. Se buscaba dar vida a un corpus documental... El tesorero Aimerico de Anteiac, compañero de prima hora y seguramente un experto en administración eclesiástica... supo dar forma a los nuevos cuerpos documentales y, como recuerda López Ferreiro, venía así a retomar el hilo de los antiguos designios historiográficos y documentales de Diego Gelmírez y sus colaboradores» ${ }^{61}$.

39 A. SICART, La miniatura, pp. 97 y ss.

an Cf. Hechos de don Berenguel, en la Bibliografía.

GCf. Hechos, p. 27. Para mejor comprobación de estas afirmaciones pongo a continuación los prólogos de estas obras:

1. Proemio al Libro 2." de las Constituciones (1328). "Quoniam humana memoria a natura est labilis... ideo ego Aymericus de Anteiacho sancte compostellanae Ecclesiae 
La intencionalidad continuadora de la escuela compostelana está bien clara y así, los comentaristas citados de los Hechos de don Berenguel siguen afirmando en su Introducción: «No sería de extrañar... que en torno a 1325, cuando con otros criterios y objetivos se elaboraban los Tumbos B y C, y el libro II de las Constituciones, se haya querido de alguna manera remendar la actividad de don Diego Gelmírez" ${ }^{62}$.

Esta escuela compostelana tiene este auge cuando ya está consolidada la escritura gótica y está a punto de producirse una modificación sustancial en la escritura del ciclo.

3.4.2. La producción codicológica. Hay, pues, hacia 1325 un relanzamiento de esta Escuela, con obras copiadas de la importancia de las ya reseñadas y, además una obra de base, que recuerda la de su antecesor en el episcopado con la Historia Compostelana, Los Hechos, o Gesta de don Berenguel de Landoira, cuya obra original debió escribirse hacia el año mencionado, aunque la copia más antigua que nos ha quedado y se conserva actualmente en el mss. 2658 de la B. de la Universidad de Salamanca esté escrita probablemente entre los años 1340 y 1350 "por un copista que escribe con cierta soltura, pero no muy meticuloso, [que] copió el texto en unos biniones que han llegado

thesaurarius de voluntate et assensu Rvdmi. patris et domini fratris Berengarii ordinis praedicatyorum... necnon de Capituli... concordi consensu, constitutiones hactenus per reverendos Patres et dominos praefate sancte Sedis Compostellane archiepiscopos et dictum capitulum editas pro conservandis ecclesiasticis libertatibus et prefati Capituli statu prospero, pacifico et tranquilo, quas dispersas reperi in diversis libris in boc volumine cum exacta diligentia recolegi, in era M.CCC.LXVI.» (LÓPEZ FERREIRO, HIC, VI, ap. XVI c), p. 76.

2. Proemio del Tumbo C. "Quoniam... Ideo ego Aymericus de Anteiacho sancte compostellane Ecclesie thesaurarius, quedam testamenta in quibus consistunt multa legata ecclesie compostellane, necnon instrumenta donationum... que in diversis et variis locis er ant dispersa et aliqua vestustate consumpta in hocvolumine transcribi feci in era M.CCC.LXVI et quotum VI idus iunii...» (LÓPEZ FERREIRO, HIC., VI, ap. XVI b), pág. 75).

3. Proemio del Tumbo B. "Quoniam humana docet experientia quod ea que sunt ab antiquis patribus honesta et bene gesta et servato rationis ordine salubriter et laudabiliter instituta temporis diuturnitate a posteriorum memoria delabuntur... Ideo venerabilis domnus Aymericus de Ameicao preffate ecclesie thesaurarius... perutile et admondum esse necessarium considerauit ut omnia Regum... testamenta... de suis originalibus transferentur et translata in uno libro quasi in uno corpore comprehendantur.

Vir itaque prefatus... non utique absque magno studio et labore hunc librum composuit et cum exacta diligentia compilavit...

Garsia Petri scripsit istum librum cum consocio suo Adefonso Petri presbitero... Rotulas vero fecit Alfonsus Petri. Fuit autem inceptus liber in era M.CCC.LXIIII, VI kalendas semptembris (LÓPEZ FERREIRO, HIC, VI, ap. XVI a).

${ }_{62}$ Ibidem, p. 40. 
a nosotros, constituyendo los actuales primeros folios del códice de Salamanca. Estos biniones... se entendió en algún momento que presentaban alguna analogía con los objetivos que se habían propuesto los autores de la Historia Compostelana, esto es, compilar materiales para una historia progresiva de la Iglesia de Santiago. Quizás por esta razón se los adhirió a un volumen de la Compostelana elaborado un siglo antes en torno a 1250" ".

Años más tarde, quizás a finales del s. XIV o comienzos del XV se hizo una nueva copia del original, más completa, que se conservó también, lo mismo que la anterior de la Compostelana, en la Catedral de Santiago. Ambos códices pasaron al Colegio Mayor del Arzobispo Fonseca de Salamanca y de allí a la biblioteca de aquella Universidad ${ }^{64}$.

De la misma época que estamos comentando he de destacar dos manuscritos, copias del Códice Calix-tino, que debieron ejecutarse en Compostela, a juzgar por la similitud entre las miniaturas de ambos códices y las que contiene el Tumbo B. de la Catedral. Estos códices son el mss. 2631 de la Biblioteca de la Universidad de Salamanca, y el mss. 128 del Archivo de san Pedro de la Biblioteca Vaticana. Ambos códices pertenecen al siglo XIV ${ }^{65}$.

Después del examen minucioso que de estos dos códices hace el Prof. Sicart, concluye: «no pueden existir dudas en cuanto al parentesco que les une, pues todos parecen derivar del mismo taller, el cual, sin duda, estaría integrado en el «scriptorium» que don Berenguel de Landore desarrolló en la Catedral Compostelana»".

Para completar el panorama codicológico, me referiré a los manuscritos conservados en la catedral de Orense, que nos son conocidos y pertenecen a este período y aún al siglo XV. Esta Catedral, según su archivero, Duro Peña ${ }^{67}$, no ha sido nunca muy abundante en códices, dada la pobreza de sus componentes capitulares; sin embargo, ha podido recoger abundantes testimonios de la existencia de libros, tomando las referencias de los documentos capitulares. Incluso, en una lista elaborada en el año 1539, se citan no menos de 54 libros litúrgicos de todo tipo, más otros «veynte e ocho cuerpos de libros escriptos a mano, nuebos e biejos, chicos e grandes, que son algunos dellos Testos e Sumas e Tratados, con sus cadenas algunos dellos" ${ }^{68}$.

¿Dónde han sido escritos estos códices? se pregunta Duro Peña; y se contesta: nadie pretenderá que todos esos libros, uno por uno, hayan sido escritos en Orense. Pero de algunos de ellos no podría negarse de plano. Por lo

${ }_{63}$ Ibidem, p. 67.

${ }^{64}$ Ibídem, p. 68. En las pp. 41-72 se hace una historia completa de la tradición de manuscritos de los Hechos.

os A. SICART, La miniatura, pp. 152-157.

on Ibidem, p. 158.

${ }^{67}$ Los códices de la Catedral de Orense, pp. 186 ss.

o8 Ibidem, p. 191. 
pronto, alguno de los códices mencionados... ostentan claros indicios de origen local... Por analogía podríamos extender la afirmación o, al menos, la sospecha a gran parte de los códices litúrgicos. Para los códices de derecho ya resulta menos probable... Incluso se conocen los nombres de algunos escribas orensanos, entre ellos Arias Fernández de Villasante, autor del Libro de Aniversarios, Martín de Yanguas, lector de Gramática y Fernando de Calderón ${ }^{69}$.

Entre los libros existentes y los fragmentos que ha podido recuperar en las encuadernaciones y guardas de manuscritos y protocolos nos da una lista de 10 códices más o menos completos, realizados entre los siglos XIII y XV, todos ellos escritos en letra gótica tradicional, sin que se especifiquen peculiaridades gallegas; y sus contenidos son: 4 de materia litúrgica y el resto de-materia jurídica, más uno que es el de Aniversarios de la Catedral. A ellos hay que añadir otros 15 fragmentos, situados también entre los siglos XIII y XV, que contienen Misales (4), Breviarios (8), Antifonarios (2) y Leccionarios (2), más otros 5 fragmentos de materia jurídica: Decretales y uno de Partidas; uno de tema bíblico y un tratado de Gramática ${ }^{70}$.

(6) Ibidem, p. 192.

${ }^{70}$ Esta es la reseña de los códices que nos interesan y que han sido inventariados por Duro Peña.

1. Missale Auriense. Consta de 228 folios de $340 \times 225 \mathrm{~mm}$. Pergamino, en letra gótica, con iniciales en azul y bermellón alternando; algunas viñetas e iniciales grandes en oro. Escrito en Orense en 1423 por Juan Gallici, malleacensis diocesis in regno Francie et predicte Ecclesie Auriensis porcionarii.

2. (Speculum iudiciale). Consta de 226 folios más dos en blanco, de $380 \times 225 \mathrm{~mm}$. Contiene los libros II, III y IV. En sendas notas al final del folio 226 v. se indican como poseedores un Alonso González, bachiller y canónigo de Orense en 1443, y un Fernando Sánchez de Calahorra, canónigo y chanciller de la iglesia y cabildo de Orense.

3. (Decretales). Consta de 88 folios de $440 \times 300 \mathrm{~mm}$. a dos columnas. Letra gótica, con iniciales en azul y rojo. Es el libro V de las Decretales de Gregorio IX con un comentario.

4. (Compilationes antiquae). Consta de 166 folios de $395 \times 245 \mathrm{~mm}$., pergamino delgado, escrito a dos columnas. Letra gótica minúscula muy cuidada. Iniciales en azul y rojo. Son unas Compilationes antiquae decretalium, con glosas. La fecha, según las deducciones del reseñador, entre los años 1215 y 1225 .

5. (Decretales). Consta de 64 folios numerados, de $322 \times 230 \mathrm{~mm}$. Pergamino, letra gótica minúscula, con iniciales e indicaciones de párrafo en rojo y azul. Decretales de Bonifacio VIII con glosa de Iohannes Monacus.

8. Summa Monaldi. Ordena las materias de Derecho en orden alfabético. Consta de 238 folios de $220 \times 150 \mathrm{~mm}$. Escrita a dos columnas en letra gótica minúscula (siglo XIV).

9. (Breviarium auriense). Breviario incompleto, al parecer «secundum consuetudinem ecclesie Auriensis», a juzgar por la inclusión de santos diocesanos. Escrito en papel, 228 
Por su parte la catedral de Tuy recoge en un inventario de 1379 «huun livro oraçoeiro, huun Avangeliorum y huun pistoleyro», y además habla de «viint e dous volumes de livros entre pequenos e grandes». En 1329 Pedro Eans, arcediano de Tuy, lega en testamento a la iglesia de Lugo «o Breviario de

folios de $216 \times 140 \mathrm{~mm}$., con iniciales en rojo y azul. La escritura del cuerpo del libro es gótica bastante cursiva, de la primera mitad del siglo XV; y la del Apéndice, de finales del s. XV.

10. (Breviarium Auriense). Consta de 397 folios de $235 \times 175 \mathrm{~mm}$., con iniciales en azul y rojo alternadas. Letra gótica, del s. XIV.

11. (Lectionarium Auriense). Comienza en la Vigilia de Navidad y llega hasta la fiesta de la Invención de San Esteban el 3 de agosto. Parece destinado al coro de la Catedral de Orense. Pergamino, Letra gótica. Iniciales en azul y rojo.

12. Liber Anniversariorum. Fundaciones de Aniversarios en la Catedral de Orense. Consta de 148 folios, de $285 \times 210 \mathrm{~mm}$., a línea tirada con espacios en blanco para intercalar nuevas fundaciones. Iniciales en rojo y azul alternadas. En el fol. 146 lleva un colofón en el que dice que su autor fue Arias Fernández de Villasante, et «fuit ceptus, concesus et perfectus in anno Domini millessimo quadringentessimo quinquagesimo secundo».

16. (Missale). Fragmento de dos folios, $360 \times 245 \mathrm{~mm}$., a dos columnas. Notación musical antigua. Misal plenario romano en la parte del Santoral. (siglo XIII).

17. Missale. Fragmento de misal plenario romano, que corresponde en lo conservado al sábado de Témporas de Cuaresma. Dos folios incompletos. Pergamino, letra gótica con iniciales en rojo y azul. Notación musical aquitana sobre línea roja (siglo XIII).

18. Misale. Fragmento de Misal romano que contiene oraciones y evangelios de las dominicas III y IV post Pentecostem con algunas ferias intermedias. Dos folios de $375 \times 250$ mm., pergamino, letra gótica del s. XIV.

19. (Missale). Fragmento de misal plenario romano que contiene el sábado de la semana tercera de Cuaresma y la dominica IV. Un folio de $400 \times 270 \mathrm{~mm}$., a dos columnas. Pergamino, en letra gótica, con iniciales en azul y rojo. Notación musical sobre línea roja. (siglo XV).

21. (Breviarium). Fragmento de un Breviario que contiene el oficio y rezo «In Annuntatione sancte Marie». Son dos folios independientes pero que parecen haber pertenecido al mismo libro. Miden $325 \times 235 \mathrm{~mm}$. Pergamino, letra gótica, iniciales en rojo y azul. Notación musical aquitana in campo aperto. (siglo XIII).

22. Breviario. Fragmento que contiene el oficio de la Degollación de Juan Bautista. Dos folios muy mutilados que miden en lo conservado $270 \times 190 \mathrm{~mm}$., pergamino, letra gótica, iniciales en rojo y azul. (siglo XIII).

23. Breviario. Fragmento que contiene oficios de Ceniza, primera semana de Cuaresma y tiempo de Pasión. Dos folios de $300 \times 215 \mathrm{~mm}$., pergamino, letra gótica, con iniciales en rojo y azul. Notación musical sobre una línea roja (siglo XIII).

24. Breviario. Fragmento que contiene las lecciones y responsorios de la fiesta de la Circuncisión. Dos folios de $300 \times 215$ mm., escrito a dos columnas. Pergamino, letra gótica, iniciales en rojo y azul. Notación musical sobre línea roja. (S. XIII-XIV).

25. Breviario. Fragmento que contiene las lecciones correspondientes al tiempo, y responsorios. Dos folios de $310 \times 220 \mathrm{~mm}$., a dos columnas. Pergamino, letra gótica, con iniciales en rojo y azul, notación musical sobre una línea roja. (siglo XIV). 
costume dessa iglesia de Lugo que son tres libros... e huun salterio françes», ...y a su criado Gerardo Pérez «as... Degretales e o ... Degesto e os libros Sestos e a Suma de Goufrido e o Compostellano e todos los outros libros de dereyto que eu ey».

26. Breviario. Fragmento que contiene lecciones y responsorios de tempore. Dos folios $310 \times 205 \mathrm{~mm}$. Aunque separados los folios parecen pertenecer al mismo libro. Pergamino, letra gótica, con iniciales, títulos e indicaciones en rojo. Notación musical sobre tinta roja. (Siglo XIII-XIV).

27. Breviario. Fragmento que contiene el oficio «In Vigilia Epiphaniae Domini» Dos folios de $360 \times 245 \mathrm{~mm}$. Letra gótica, iniciales y capitales en rojo y algunas en negro. Notación musical sobre una línea roja. (Siglo XIII).

28. Breviario. Fragmento de una parte de tempore. Dos folios de $385 \times 250 \mathrm{~mm}$., a dos columnas. Pergamino, letra gótica; iniciales, títulos e indicaciones en rojo; notación musical sobre una línea roja. (Siglo XIV).

29. Breviario. Contiene lecciones y responsorios de la fiesta de Navidad. Un folio de $445 \times 300 \mathrm{~mm}$. a dos columnas. Pergamino, letra gótica, con iniciales en rojo y azul. Notación musical antigüa sobre una línea roja. (Siglo XIV).

30. Breviario. Contiene una parte del oficio de tempore. Un folio de $290 \times 250$ $\mathrm{mm}$., con un fragmento de otro folio unido. Pergamino, letra gótica; iniciales y títulos en rojo. Notación sobre línea roja. (Siglo XIV).

33. Antifonarib. Fragmento que corresponde a los oficios de san Juan Apóstol y Santos Inocentes. Dos folios de $300 \times 210 \mathrm{~mm}$., a renglón seguido. Pergamino, letra gótica, iniciales en rojo y azul. Notación musical antigua sobre línea roja. (Siglo XV).

34. Antifonario. Fragmento que corresponde al tiempo de Adviento. Bifolio de 330 $\times 220 \mathrm{~mm}$., a línea tendida. Pergamino, letra gótica, iniciales en rojo y azul. Notación musical sobre línea roja. (Siglo XIV-XV).

35. Leccionario. Parece un fragmento de un leccionario de Coro. Dos folios unidos de $450 \times 300 \mathrm{~mm}$., escrito a dos columnas. Pergamino, letra gótica, con iniciales alternadas en rojo y azul. (Siglo XIV).

36. Epistolario y Evangeliario. Tres folios sueltos: uno y un bifolio, de $500 \times 340$ $\mathrm{mm}$., pergamino, letra gótica, iniciales como de costumbre. (Siglos XIV-XV).

37. Decretales. Parece un fragmento de Decretales. Dos folios de $250 \times 150 \mathrm{~mm}$., a dos columnas. Pergamino, letra gótica, iniciales en rojo y azul. (Siglo XIV).

39. Jurídico. Frag., ento de códice jurídico, bifolio cosido de $330 \times 225 \mathrm{~mm}$., Pergamino, letra gótica, capitales y títulos en rojo. (Siglo XIV).

40. Jurídico. Fragmento de texto jurídico, bifolio de $400 \times 250 \mathrm{~mm}$. Pergamino, letra gótica, capitales en rojo y azul alternadas. (S. XIV).

41. Sexta Partida. Fragmento de la VI Partida que comprende el título VII y parte del VIII, de $300 \times 220 \mathrm{~mm}$., Pergamino, letra gótica redonda, iniciales en rojo y azul alternadas. (Siglo XIV).

42. Decretales. Sirviendo de cubierta a los legajos del archivo de la Catedral de Orense; A) Escrituras IV; B) Escrituras X; C) Escrituras XI; D) Escrituras XVIII; E) Obispo. Estos fragmentos, salvo los cuatro folios del primero, parecen haber pertenecido al mismo códice. En total, 12 folios, más otros 4 de otro códice diferente. Todos ellos de materia 
Y todavía podemos completar la serie de códices de esta época con la Biblia del convento de Santo Domingo de Santiago, que debió ser escrita en París a finales del siglo XIII, actualmente en la B.N. de Madrid, núm. 559. con la Biblia de la Universidad de Santiago, escrita a principios del siglo XIV, de procedencia parisina, que perteneció a la Biblioteca del Colegio de la Compañía de Jesús de Monterrey (Verín, Orense); y con el Pontifical de la Catedral de Tuy, procedente con toda seguridad de Italia y de influencia boloñesa ${ }^{72}$.

3.4.3. La escritura documental. Siglos XIII - XIV. Tradicionalmente se viene colocando a mediados del siglo XIII una censura en la evolución de la minúscula diplomática, porque a comienzos del reinado de Alfonso $\mathrm{X}$ se producen unas novedades documentales, que alcanzan también a los modelos gráficos. Se habla de modo definitivo de la escritura gótica documental, repartida en dos grupos: el caligráfico o escritura de privilegios; y el cursivo, o escritura de albalaes.

Esta división, llevada al campo de la documentación privada, en la que se incluye la notarial, necesita en Galicia algunas consideraciones que paso a exponer. Tomo como punto de partida la mitad del siglo XIII por tres razones: la primera y menos importante, la tradición ya implantada; la segunda, porque en torno a estos años se implanta definitivamente el notariado como sistema documental con plena autenticidad para sus escritos en la persona de los notarios; y la tercera, durante la segunda mitad de este siglo se produce el fenómeno de la utilización progresiva y definitiva del gallego en los documentos.

3.4.3.1. Los origenes del notariado y el uso del idioma gallego. Ambos factores son para mí decisivos. El notariado me ha preocupado desde hace mucho tiempo y a él he dedicado bastante atención, desde el capítulo que en mi tesis doctoral escribí sobre el notariado compostelano a través de la documentación de san Martín Pinario ${ }^{73}$, hasta los trabajos más recientes de Oseira y

jurídica: Decretales. Letra gótica, epígrafes e iniciales en colores usuales. (Siglos XIV$\mathrm{XV})$.

45. Bíblico. Fragmento que contiene Éxodo y Números. Cuatro folios sueltos del mismo códice, de $361 \times 264 \mathrm{~mm}$. Letra gótica, iniciales en rojo y azul alternadas. (Siglo XIII).

46. Homilías? Puede ser un fragmento de Homiliario. Tres folios de $330 \times 210$ mm., a línea tendida. Letra gótica, iniciales usuales. (Siglo XIII, mutilado en parte).

47. Gramática. Fragmento de un bifolio en papel $293 \times 220 \mathrm{~mm}$., gótica cursiva con iniciales en rojo y azul, que contiene cuestiones de Gramática. (Siglo XV).

$"$ P. Galindo ROMEO, Tuy, pp. 98-99. 144.

12 Descripción de estos tres manuscritos en A. SICART, La miniatura, pp. 104-

73 M. Lucas Álvarez, Colección Diplomática de San Martín P. (Tesis doctoral, inédita). 
Camanzo ${ }^{74}$. En todos ellos he visto la trayectoria evolutiva del notariado, que arranca, en el caso de Compostela, de los últimos años del s. XII, con la aparición de unos notarii iurati del concejo, probablemente sólo hábiles para documentos concejiles, pero con formación profesional de escritura, y que he podido comprobar también en fechas poco posteriores en otras partes de Galicia, y sigue con el asentamiento progresivo de la institución en los decenios medios del siglo, adelantándose o amparándose en la doctrina alfonsí del Espéculo y Partidas.

Este hecho jurídico comporta unas modificaciones importantes en la estructura de los documentos y un ejercicio de la escritura que cambia moldes antiguos de aprendizaje escolar y tiende -a mi modo de ver- a aprendizaje de taller notarial, aprendido en cada una de las notarías en una especie de pequeño "cursus» de ascensos profesionales y que pasa por los exámenes y aprendizaje de amanuense a notario sustituto y a notario definitivo.

La escritura y sus cambios corren paralelos al desarrollo notarial y a la individualidad de las escrituras puede asociarse la compleja organización de los territorios o espacios notariales.

Por lo que respecta al idioma, los exámenes que he realizado en grupos de escrituras de esta época y de varias procedencias me permiten llegar a unas conclusiones provisionales que, tanto en Santiago como en Camanzo y Oseira, son muy similares. El comienzo efectivo del uso del gallego en los documentos no debe situarse antes de 1250; y los documentos que, con anterioridad a esta fecha se puedan encontrar, o son excepción, o se trata de copias traducidas de originales latinos.

Entre 1250 y 1265 se encuentran los primeros ejemplares escritos en gallego en nuestra documentación notarial y privada. En el caso del monasterio de Oseira, de 312 documentos examinados, 293 están en latín y sólo 9 en gallego.

A partir de los años 1265-1270 y hasta la finalización del siglo, el gallego incrementa rápida y progresivamente su aparición; y desde 1301 en adelante la documentación en latín es una excepción o un campo reservado para asuntos de administración eclesiástica".

La utilización de una u otra forma de expresión no está relacionada, al menos en principio, con la procedencia del notario o escriba «clérigo/laico, iuratus o del Rey" y el gallego penetra como una suerte de democratización en el campo del documento gallego y alcanza a la escritura, haciéndola más familiar e individualizada dentro de las distintas familias notariales. Incluso

${ }^{74}$ Id. Id., La Colección diplomática del monasterio de Camanzo y Documentos notariales de Osera. Cf. Bibliografía.

75 Documentos notariales de Osera, pp. 239-240. 
muchos notarios utilizan indistintamente el latín o el gallego en escrituras coetáneas.

3.4.3.4. Las distintas formas gráficas del ciclo. Dicho lo anterior analizo el fenómeno gráfico en su morfología y, salvo alguna variante en la nomenclatura, puedo suscribir para toda la región lo que hace unos años decía del ámbito compostelano ${ }^{76}$.

a) Afirmaba en este trabajo que en un examen general de las escrituras notariales desde la segunda mitad del siglo XIII se encuentra el investigador con grupos de notarios o amanuenses, cuyas escrituras recuerdan la minúscula diplomática tradicional, especialmente en sus vertientes corriente y cursiva, si bien el apuntamiento de los rasgos, la fractura interna de la contextura de cada signo, la presencia permanente de una $d$ uncial y la ondulación de los astiles y caidos, y la forma concreta del caido y bucle de la letra $g$ denuncian el acoso de las formas góticas.

El grupo de amanuenses que cultivan esta forma se puede situar entre los años 1250 y 1300 , y sus formas son tan variadas que en muchos casos plantean problemas de clasificación de un texto dentro del grupo o del que seguidamente vamos a considerar. (Ver láminas 3.4.3.2/1 a 14).

b) Entremezclado con el grupo anterior y superándole en cronología hasta introducirse en el siglo XIV durante su primera mitad se encuentran otras formas de escritura que pueden calificarse de góticas, y aún de góticas de Galicia, a juzgar por algunas maneras arcaizantes, rudas y pesadas, propias de una escritura de ambientes rurales o ruralizados. Dentro del grupo podemos apreciar pequeñas diferencias:

b.1) Una escritura de carácter caligráfico que, en ocasiones puede recordar las formas codicológicas (cf. Láminas 3.4.3.2/15, 16 y 17).

b.2) En una gran mayoría de casos se inscribe en un tipo currens o cursivo, de características similares a la tradicional gótica de albalaes o cursiva y trazado de variado cuidado. (cf. láminas 3.4.3.2./18 a 35), con variedades gráficas individuales en las que no podemos entrar ahora, pero comprobables a la vista de los textos.

c) Pasada la cuarta decena del siglo XIV se perfila una nueva modalidad en el tratamiento de las escrituras y de la letra. Se comienzan a ver letras con perfiles redondeados y poco partidarias de las quebraduras violentas. Precisamente esta tendencia, que es general en la escritura de Galicia, crea dificultades a la hora de detectar estas nuevas manifestaciones de la gótica, pero progresiva-

76 Id., Id. Escritura gótica gallega, pp. 53-86 (Cf. Bibliografía). Desde hace años me dedico al estudio de escrituras de Galicia entre los años $125-1350$ y a la vista de lo analizado hasta el presente -documentación privada de la Catedral de Orense, monasterios de Ramirás y Montederramo y otras colecciones menores- puedo reafirmarme en estas conclusiones provisionales. 
mente en el resto del siglo se puede advertir el incremento de la cursividad, el desarrollo ampuloso de nexos de amplias curvas y la proliferación de rasgos superfluos y signos complementarios de valor indefinible, que constituyen aquí, lo mismo que en el resto de los territorios peninsulares de occidente, los comienzos del grupo llamado precortesano.

El fenómeno, iniciado a mediados del siglo, desemboca al comenzar el siguiente en una cortesana de múltiples formas, desde la textual a la cursiva propia y la procesal. (Cf. láminas 3.4.3.2./26-45).

Como complemento de estas observaciones generales de los grupos documentales góticos, remito al Apéndice gráfico una serie de signos y sistemas abreviativos que pueden ser útiles para el análisis de estos grupos. (Cf. láminas 3.4.3.2/46 y 47). Algunas de tales formas pueden considerarse propias de los sistemas galaicos, como las de "Que presentes foron», derivada de la latina Qui presentes fuerunt; y la de "quen quer que» o "Qui/que quer que».

Llamo la atención, sobre todo, de la importancia que en los documentos en gallego tiene la existencia del signo diacrítico. Las virgulillas que desde el s. XII son frecuentes en cualquier texto paleográfico para señalar la presencia de la doble ii, pasan en la escritura gótica de Galicia a una floración de signos aplicables, no sólo a la doble $i i$, sino a las vocales duplicadas, cualquiera que sea su sonido: $a a, e e, o o, u u$, y ya se encuentren en la misma palabra o en palabras separadas, dando la impresión de que el escriba quiere señalar con este signo no sólo la duplicación sino el sonido más o menos obscuro con que ambas letras pueden ser pronunciadas. La importancia de tales signos es grande para el paleógrafo, si quiere presentar unos textos que sean útiles para historiadores y filólogos, a la vez.

3.5. El siglo XV. Quizá el menos singular de todos en lo referente a formas de escritura. Galicia se adapta íntegramente a las corrientes que dominan en los reinos occidentales peninsulares, de los que forma parte. La escritura llamada cortesana domina el ámbito escritorio documental; y en los códices predominan las mismas letras góticas de épocas anteriores, dentro de lo poco que hemos podido examinar. Cuando se trata de ejemplares litúrgicos o universitarios las letras son las góticas de forma o las textuales; cuando son libros de actas capitulares, consistoriales, de cuentas, etc., las letras cortesanas formadas o semicursivas. Toda vez que sus caracteres se estudian en otras lecciones de este mismo curso, no voy a repetir cuanto en ellas se haya de afirmar.

3.5.1. Bibliotecas y códices del $s . X V$. La obra cumbre de este siglo es, sin duda, el llamado Breviario de Miranda, joya conservada en el archivo catedral de Santiago. Es un manuscrito de 514 folios en cuarto menor, escrito muy posiblemente en Santiago, quizá hacia los años 1476. Fueron sus poseedores, aunque no los primeros, los canónigos Pedro de Miranda o Luis de 
Miranda, que figuran en las Actas capitulares entre 1481 y 1483 . Sicart, que ha prestado gran atención a este manuscrito, supone con fundamento que quizá el que encargó el Breviario y su primer poseedor fue don Fernando Ruiz de Castro, que aparece como canónigo en el año 1446, en 1460 era Arcediano de Nendos y en 1489 Deán de la Catedral. Su vinculación con la casa nobiliaria de Lemos y los cargos importantes que tuvo en la Catedral le hacen buen candidato al encargo de este Breviario y, por otra parte, sus armas figuran en los símbolos heráldicos que decoran muchas de las páginas de este códice ". Su letra es la característica gótica de forma y son especialmente importantes las miniaturas, orlas, capitales, etc. que decoran prácticamente cada una de las páginas del libro.

Después de este manuscrito se pueden señalar los que anteriormente he reseñado de la Catedral de Orense, y que pertenecen a este siglo; el adquirido en 1982 por el Museo de Pontevedra, procedente de la Biblioteca de don José Menéndez Pidal, que contiene la Historia Compostelana y fue escrito hacia 1470 , tomando como modelo casi seguro el ejemplar que se conserva en la Biblioteca de la Universidad de Salamanca, del que más arriba hice mención ${ }^{7-}$ bs. $\mathrm{Y}$ algunos otros de menor importancia, que contienen cartularios, actas capitulares, etc.

En cuanto a Bibliotecas, aparte de la escasa información que suministra Ambrosio de Morales en su Viaje Santo ${ }^{78}$, podemos seguir los datos contenidos en la obra de López Ferreiro, Galicia en el siglo XV ${ }^{79}$, que ha recogido informaciones documentales al respecto. En un Acta capitular del cabildo de Santiago de 4 de enero de 1497 se hace la anotación de los libros que se llevan de la librería del Cabildo Pedro de Muros y Gómez Vello «para los remediar». Son en total 51 libros en pergamino o papel los que necesitan reparación y entre ellos abundan los de Derecho. «Sensible es -dice López Ferreiro- que no conozcamos el inventario de los códices que no necesitaban reparación, el cual debería ser no menos copioson. Alude, asimismo, al hecho de la fundación de la librería del Cabildo, que tuvo lugar en el año 1446, con libros donados por el card. Juan do Barro, con el encargo de «que os ditos libros sejan deputados para huna libraria da dita eglesia e non para outra cousa... que por quanto a $o$ presente non está feita a tal libraria, nen lugar deputado para ela... que os señores do dito cabidoo sejan obligados de fazer e mandar fazer a dita libraria...». Como consecuencia de esta donación se llevó a cabo esta biblioteca,

7 A. SiCART, La miniatura, p. 161. Estudio completo entre las pp. 159 y 169.

77bis Cf. sobre este códice el trabajo de José GARCÍA ORÓ, Un nuevo testigo, esp. pp. 344-352, que nos da las primeras informaciones sobre su contenido, data y posible procedencia.

78 A. MORALES, Viaje Santo, pp. 113-167.

79 Conf. pp. 219-229. 
como consta en repetidas actas documentales del cabildo, que ha recogido López Ferreiro.

En la Catedral estaban depositados también los códices mencionados; y entre ellos una Cbronica Martiniana de fr. Martinus Polonus ex ordine Predicatorum, seguida del Rosarius de virtutibus et vitiis, escrito en el año 1413 de orden del Arzobispo de Santiago, don Lope de Mendoza, por el canónigo Isebrando Macía; y otros más que debían existir por entonces y que posteriormente han servido de forros y guardas a los protocolos notariales del cabildo en el $\mathbf{s}$. XVI.

Además de esta biblioteca catedralicia consta la existencia en Santiago de una biblioteca pequeña en el Hospital de san Miguel, fundada por el canónigo compostelano Ruy Sánchez de Moscoso, y en ella había libros de Teología, Física, Medicina y Derechos.

En Lugo dice Villaamil y Castro en Los Códices de las Iglesias de Galicia, citando a López Ferreiro, «De los cincuenta o sesenta códices que enumera como pertenecientes a la iglesia de Lugo durante los siglos XIII y XIV, muy pocos podían conservarse a mediados del siglo $\mathrm{XV}^{80}$.

En la catedral de Mondoñedo, según el informe elaborado en 1572 por los canónigos para enviar a Ambrosio de Morales, se deduce que existían al menos ocho códices: 1, Exposición del Salterio; 2, un Liber scinthilarum; 3, algunas partes de la Biblia; 4, dos glosas, una del libro de los Cantares y otra sobre el de Job; 5, una breve exposición de la Sagrada Escritura sin nombre de autor; 6, un libro de Sermones; 7, una Crónica, que quizá era la Martiniana; y 8, un libro de Sermones.

De los monasterios las noticias son nulas y sigue la información negativa que suministra el propio Morales. En cuanto a bibliotecas particulares serñala la del regidor compostelano Francisco de Treviño, fallecido en 1511, que enumera 26 libros de todo tipo, escritos a mano o «de molde», es decir, impresos ${ }^{\text {B1 }}$.

Por último, de la Catedral de Tuy, tenemos información a través de las noticias recogidas por Galindo Romeo. En 1436 recibía el cabildo de Tuy de su obispo el Card. de san Pedro ad Vincula «hunas Degrataes e hunas Crementinas e huun Ignoçençio e huun Epoloco e huun Decreto e huun Rosario e huun Dejesto e huun Codigo». En 1461 visita el tesoro de la Catedral el maestrescuela Vasco Lourenço y dice «que tevera o Breviario françes que el ey don Enrique deu... (y) que tina mays hunas Degretaes desta dita Iglesia». Por último, en un

80 Ibidem, p. 226.

${ }^{81}$ Ibidem, pp. 228-229. 
acta capitular de 1463 figuran: «Hun Arçediano sobre Sesto, outro arçediano sobre o Decreto, huun Betulo, huna Estatuta», y otros varios ${ }^{82}$.

3.5.2. Las grafías de las Actas capitulares,... En la pequeña colección que acompaña a estas notas recojo una muestra de escrituras procedentes del libro de Consistorios del Concejo de Santiago, del Livro do Concello de Pontevedra y de los Protocolos de la Catedral de Tuy. Mi intento es señalar la frecuencia de este tipo de libros y otros más, como las actas capitulares de Santiago o Lugo y Mondoñedo, libros de Protocolos de entidades catedralicias o monásticas etc., con el fin de colegir la posible existencia de una letra típica de los «Registros o protocolos».

La realidad es que no se puede definir con precisión; y si nos fijamos, p. ej., en el Livro do Concello pontevedrés, o en los protocolos notariales de Tuy, llegaremos fácilmente a la conclusión de que su estructura es la de una "cortesana rápida», cargada de abreviaturas y de omisiones formularias suplidas por un etc., pero no sirve de base para formular una doctrina gráfica sobre este tipo de libros.

Las actas capitulares, con anterioridad al s. XV, han sido recogidas como un documento más en las colecciones documentales de cada época y responden a las características gráficas de tales colecciones o Tumbos, y el ejemplo del Libro de Consistorios de Compostela nos enfrenta con unas variantes que van desde una cortesana textual a la mayor cursividad dentro de ella.

Sobre los protocolos de este siglo, debo decir que las series conocidas, casi siempre de entidades eclesiásticas, salvo los concejiles de Orense, responden a colecciones de documentos o notas de un determinado notario, redactados y signados con todas las características de originales y con los mismos tipos de letra de tales originales. (Cf. láminas 3.5.2./1-12).

3.5.3. Documentos notariales y privados. Sus estructuras gráficas siguen las modas del momento. Quienes hayan necesidad de un documento notarial o incluso privado buscan la colaboración de expertos y solicitan de ellos los modelos de escritura que se adaptan a su conveniencia, y que pueden ser los caligráficos de tipo redondo o los más cursivos de la cortesana, en una gama similar a la que podemos encontrar en Castilla en la misma época. No hay discrepancias en las formas gallegas y, consiguientemente, no necesitan anotaciones particulares.

Para justificar mis afirmaciones pueden verse las láminas 3.5.3./1 a 8 que acompañan como Material gráfico.

82 P. Galindo Romeo, Tuy, pp. 97-101. 


\title{
4. LÍNEAS DE TRABAJO POSIBLES
}

A modo de conclusiones señalaré algunas líneas de trabajo o estudios deseables en un futuro próximo.

1. No parece factible que se modifique el esquema de la escritura visigótica, pero hay una línea de trabajo ya iniciada por el Prof. Díaz, que investiga cualquier fragmento que pueda encontrar en las guardas o encuadernaciones de libros antiguos y que hasta el momento viene dando aportaciones con resultados positivos.

2. El Departamento de Paleografía y yo, personalmente, trabajo desde hace unos años en la documentación de los años 1250 a 1350, para seguir las fluctuaciones y novedades que se producen en este tiempo, tanto en lo diplomático como en lo paleográfico y filológico. La investigación debe proseguir hasta el final.

3. Es interesante seguir la evolución paleográfica de los siglos XIV y XV en las zonas fronterizas con Portugal, especialmente en los Archivos de Orense y Tuy, porque pueden aportar datos valiosos para mutuas influencias, tanto gráficas como abreviativas y filológicas en los documentos de ambas zonas.

4. Necesario también emprender con los filólogos una colaboración decisiva para dotar a nuestros investigadores de unas Normas de transcripción de documentos en gallego que sean válidas para cuantos se interesan por estos temas. Tales contactos deben extenderse a los paleógrafos portugueses por las relaciones idiomáticas de ambos territorios ${ }^{83}$.

\author{
MANUEl LUCAS ÁlVARez \\ Universidad de Santiago de Compostela
}

83 Mi trabajo Para unas normas complementarias de transcripción de documentos en gallego, "CEG», XII (1949), pp. 95-110, debe ser revisado de acuerdo con las actuales Normas ortográficas e morfolóxicas do idioma galego, elaboradas por la Real Academia Gallega y O Instituto da Lingua galega (Vigo), 1982, y que rigen como oficiales por acuerdo de la Xunta de Galicia. La colaboración con los filólogos y paleógrafos portugueses será muy beneficiosa y enriquecedora. 


\section{BIBLIOGRAFÍA}

ACUÑa CASTROVIEjo (Fernando), Bibliografía de Galicia Romana, "Actas del Coloquio Internacional sobre el Bimilenario de Lugo», Lugo, 1977, pp. 186-189. ÁLVAREZ BLÁZQUEZ (José María), Vid. Inscripciones romanas de Galicia, Suplemento III.

ARIAS (Maximino), Informe sobre el archivo del monasterio de Samos, "Actas de las I Jornadas de Metodología aplicada a las Ciencias Históricas». V. Paleografía y Archivística, Santiago, 1975, Fundación Universitaria Española y Secretariado de Publicaciones de la Universidad, pp. 163-169.

ARIAS VILlAS (Felipe) -Le ROUX (P.)- TRANOY (A.), Inscriptions romaines de la province de Lugo, París, Diffusion de Boccard, 1979, 132 pp. 33 lams.

ARCHIVO HISTÓRICO DIOCESANO, Santiago de Compostela. Inventario del fondo general, Santiago, 1977. Servicio de Publicaciones de la Fundación «Pedro Barrié de la Maza Conde de Fenosa", 94 pp. Presentación por Salvador Domato Búa.

Bouza ÁlvareZ (Emilia), Orígenes de la Notaria. Notarios en Santiago de 1100 a 1400, «Compostellanum», V-4 (1960), pp. 233-412.

BOUZA BREY (Fermín), Vid. Inscripciones romanas de Galicia, I, IV y Suplemento III.

CAl PARdo (Enrique), El Archivo de la Catedral de Mondoñedo, "Actas de las I Jornadas...», Santiago, 1975, pp. 133-143.

-, Catálogo de los documentos medievales escritos en pergamino del Archivo de la Catedral de Mondoñedo (871-1492), Lugo, Diputación Provincial, 1990.

CASTILLO (Ángel del), Vid. Inscripciones romanas de Galicia, Suplemento I.

CASTRO VÁZQUEZ (Josefina), Contribución a la tipología epigráfica de la Gallaecia romana. Tesis de Licenciatura (inédita), Santiago, Facultad de Filosofía y Letras, s/a.

-, Contribución a la epigrafía de la Gallaecia romana, «BCPM» Lugo, IX (1973), pp. 145-150.

DíAZ Y DíAZ (Manuel C.), Problemas de la cultura en los siglos XI-XII. La escuela episcopal de Santiago, "Compostellanum», XVI (1971), pp. 187-206.

-, Códices visigóticos de la monarquía leonesa, León, Centro de Estudios e Investigación "San Isidoro», Caja de Ahorros M. de P., Archivo Diocesano de León, León, 1983. 563 pp. lams. Citado: Códices.

-, El Códice calixtino de la Catedral de Santiago. Estudio codicológico y de contenido, Santiago, Centro de Estudios Jacobeos, Monografías de "Compostellanum», 2, 1988.

Domato Búa (Salvador), El Archivo Histórico Diocesano de Santiago de Compostela. Sondeo documental, «Actas de las I Jornadas...», Santiago, 1975, pp. 101-108. 
-, Guia-inventario de archivos parroquiales de la diócesis de Santiago de Compostela. Proyecto y primeros resultados, Ibidem, pp. 109-132.

DuRo Peña (Emilio), Los códices de la Catedral de Orense, "Hispania Sacra», XIV-27 (1962), pp. 185-212.

-, Catálogo de los documentos reales del archivo de la Catedral de Orense, «Miscelánea de Textos Medievales», 1 (1972), pp. 9-145.

-, Catálogo de los documentos privados en pergamino del Archivo de la Catedral de Orense, Orense, Instituto de Estudios Orensanos «Padre Feijoo», 1973, pp. 475.

EijÁn Moyano (María Gloria), Monarterio de Santa Clara de Santiago de Compostela, Santiago, 1969 (Tesis de Licenciatura, inédita).

FERNÁNDEZ Y FERNÁNDEZ (José María), Índice de los fondos históricos que se guardan en el Archivo del Palacio episcopal de Mondoñedo, "Actas de las I Jornadas...", Santiago, 1975, pp. 145-150.

FERNÁNDEZ-VILlAMIL ALEGre (Enrique), Documentos medievales del Museo de Pontevedra. Siglos XII-XIII, «El Museo de Pontevedra», II (1943), pp. 111-120.

-, Documentos medievales del Museo de Pontevedra. Siglo XIV, «El Museo de Pontevedra», III (1944), pp. 125-146.

-, Las antiguas Cofradias gremiales pontevedresas, "Revista de Trabajo», Madrid, 5 (1944), pp. 579-593; 8 (1944), pp. 983-1010; 9 (1944), pp. 1103-1134.

Ferro Cousello (Xesús), A vida e a fala dos devanceiros. Escolma de documentos en galego dos seculos XII a o XVI, Vigo, Galaxia, 1967, 2 vols. 228 y 479 pp. Citado: Vida e fala.

Filgueira Valverde (J.F.), Archivo de mareantes, Pontevedra, Gráficas Torres, 1946.

-, Vid. Inscripciones romanas de Galicia, III.

Galindo RoMeO (Pascual), Tuy en la baja Edad Media. (Siglos XII-XV), Madrid, 1923, $203 \mathrm{pp}$.

GarCía CONDE (A.), El Archivo de la Catedral de Lugo, «BCPM Lugo», II-3/4 (1947), pp. 4-21.

GIL MERINO (Antonio), Archivo Histórico del Reino de Galicia. Guia del investigador, Madrid, MEC. D.G. del Patrimonio Artístico y Cultural, 1976, 219 pp. Citado: ARG. Guia.

GÓMEZ SOBRINO (Jesús), El Archivo Diocesano de Tuy y la centralización de los libros parroquiales, "Actas de las I Jornadas...», Santiago, 1975, pp. 157-161.

HECHOS de don Berenguel de Landoria, Arzobispo de Santiago. Introducción, edición crítica y traducción por el Equipo de Investigación "Galicia 1500», Santiago, Secretariado de Publicaciones de la Universidad, 1983, 204 pp. Citado: Hechos.

INSCRIPCIONES ROMANAS DE GALICIA, Edición por el Instituto P. Sarmiento de Estudios Gallegos.

Contenido:

I.-Santiago de Compostela, por F. BOUZA BREY y Álvaro d'ORS, Santiago, 1949.

II.- Provincia de Lugo, por F. VÁZQUeZ SACO y M. VÁzQUEZ SeIJAS, Santiago, 1954. 
III.- Museo de Pontevedra, por Á. d'OrS y J. Filgueira VAlverde, Santiago, 1966.

IV.- Provincia de Orense, por F. BOUZA BREY, Á. d'ORS, X. LORENZO FERnánDEZ, Santiago, 1968.

Suplemento I, Provincia de La Coruña, por Ángel del CASTILlO y Álvaro d'ORS, Santiago, 1960.

Suplemento III, Vigo, Por F. BouZa Brey y J.M. Álvarez BlázQueZ, Santiago, 1961.

JIMÉNEZ GÓMEZ (Santiago), Guía para el estudio de la Edad Media gallega (11001480), Universidad de Santiago, 1973, 168 pp. Citado: Guia.

Justo Martín, (M. Xosé), Arquivo Histórico Universitario. Guía, Universidad de Santiago de Compostela, s.a. [1990].

LE ROUX (P.), Vid. ARIAS Villas (F.)

LEBÓN SÁNCHEZ (José), El archivo diocesano de Lugo. Sondeo documental, "Actas de las I Jornadas...", Santiago, 1975, pp. 151-156.

LEIRÓs FERNÁNDEZ (Eladio), Catálogo de los pergaminos monacales del Archivo de la S.I. Catedral de Orense, Santiago, 1951, Bibliotecas y Archivos eclesiásticos, I, Publicaciones de la D.G. de Archivos y Bibliotecas, 550 pp.

LÓPEZ ALSINA (Fernando), Introducción al fenómeno urbano medieval gallego a través de tres ejemplos: Mondoñedo, Viveiro y Ribadeo, Santiago, Universidad, 1976, 155 pp., láms. y apéndice con extractos documentales.

LÓPEZ FERreiro (Antonio), Historia de la Santa A.M. Iglesia de Santiago de Compostela, Santiago 1898. (Interesan los tomos II a VII). Citado: HIC.

-, Galicia en el último tercio del siglo XV, Ed. 3.' corregida por Ramón Fernández Pousa, Faro de Vigo, 1968, 294 pp. Citado: Galicia.

LÓPEZ GÓMEZ (Pedro), Archivo Histórico Provincial de Pontevedra. Guía del investigador, Pontevedra, MEC, D.G. del Patrimonio Artístico y Cultural 1977, 167 pp.

LORENZO FERNÁNDEZ (X.), Vid. Inscripciones romanas de Galicia, IV.

LOSCERTALES (Pilar), Tumbos del Monasterio de Sobrado de los Monjes, Madrid, D.G. del Patrimonio Artístico y Cultural, AHN, 1976, 2 vols. 544 y 708 pp.

LUCAS ÁlVAREZ (Manuel), Estudio bistórico-diplomático de la colección documental del monasterio de san Martín Pinario de Santiago, Santiago-Madrid, 1948 (Tesis doctoral, inédita).

-, Catálogo de los fondos en pergamino existentes en el Archivo de la Universidad de Santiago de Compostela, Sección 2.", Fondo del monasterio de San Martín Pinario, B.U. Santiago, LI-LII, (1948), pp. 99-131.

-, Estudios de Paleografía visigótica en Galicia, 1951 (inédito).

-, En torno a un documento atribuido al monasterio de Meira, "CEG», XXII (1952), pp. 353-369.

-, La Colección diplomática del monasterio de san Lorenzo de Carboeiro, "Compostellanum», II-4 (1957), pp. 550-573; III-2 (1958), pp. 223-308; III-4 (1958), pp. 548-638.

-, Documentos notariales y notarios en el monasterio de Osera, "Actas de las I Jornadas...», Santiago, 1975, pp. 223-240. Citado: Notarios de Osera. 
-, El monasterio de san Julián de Moraime en Galicia. (Notas documentales), «Homenaje a D. Agustín Millares Carlo», Las Palmas, 1975, II, pp. 605-643.

-, El monasterio de san Salvador de Camanzo, «Archivos Leoneses», 64 (1978), pp. 273-379.

-, El Archivo del monasterio de san Pedro de Ramirás en la Edad Media, "Compostellanum», XXIV 1/4 (1981), pp. 7-35.

-, El Tumbo de San Julián de Lamos (siglos VIII-XII). Estudio introductorio. Ediciones diplomáticas. Apéndices e Indices, Santiago de C., Caixa Galicia, 1986.

LUCAS (M.), El Notariado de Galicia basta el año 1300 (Una aproximación) en «Notariado público y documento privado de los orígenes al siglo XIV. Actas del VII Congreso Internacional de Diplomática», Valencia, 1986, Generalidad Valenciana, Conselleria de Cultura, Educació i Ciència, 1989, 2 vols.. pp. 331-480.

-, y LUCAS DOMínguez (Pedro), San Pedro de Ramirás. Un monasterio femenino en la Edad Medida. Colección diplomática, Santiago de C., Caixa Galicia, 1988.

-, JUSTO (María Xosé), y LUCAS DOMíNGUEZ (Pedro), Fontes documentas da Universidade de Santiago de Compostela, Serie BENS do Arquivo Universitario (Anos 1237-1537) Edición diplomática, Santiago de C., Consello da Cultura Galega, 1991.

MARTÍNEZ SAlAZAR (Andrés), Los documentos más antiguos de España?, "Galicia Histórica», 1 (1901-1902), pp. 788-799.

-, Diplomática gallega, ¿el último representante de la letra visigoda?, "Bragallega», VIII-74 (1913), pp. 49-56.

MillaRes CARLO (Agustín), Los códices visigóticas de la Catedral de Toledo, Madrid, 1935.

-, Tratado de Paleografía Española, Madrid, Espasa Calpe S.A., 3." ed., 1983, 3 vols.

MORALES (Ambrosio de), Viaje de -..--- por orden del rey Pbelipe II a los reynos de León y Galicia y principado de Asturias, Ed. facsímil con prólogo de José M. ORTIZ JUARES, sobre la ed. del P. FLÓREZ de 1765, Oviedo, 1979, 224 pp.

MONT (H.), Catalogue de la Bibliothèque de Bernard II, archévêque de Saint-Jacquesde-Compostelle, 1226, en «BECH», 54 (1983), pp. 327-333.

ORS (Álvaro d'), Vid. Inscripciones romanas de Galicia, I, III, IV y Suplemento I.

PALlARÉS MÉNDEZ (María del Carmen), El monasterio de Sobrado: un ejemplo del protagonismo.monástico en la Galicia medieval, La Coruña, Publicaciones de la Excma. Diputación Provincial, 1979, 340 pp.

PORTELA SILVA (Ermelindo), La región del obispado de Tuy en los siglos XII al XV. Una sociedad en la expansión y en la crisis, Santiago, 1976.

POSADA (María Guadalupe), Documentos del notario Pedro de Lagea para la Catedral de Tuy, Santiago, Facultad de Filosofía y Letras, s.a. (Tesis de Licenciatura, inédita).

Privilegios reales y Viejos Documentos. III. Santiago de Compostela, I-XI, Madrid, Joyas Bibliográficas, 1965.

RODRÍGUEZ GALDO (María Xosé), Señores y campesinos en Galicia. Siglos XIV-XV, Santiago, Ed. Picrosacro, 1976, 316 pp. 
RODRÍGUeZ GonZÁlez (A.) Millás (Isidoro), Documentos para la Historia de Pontevedra medieval. "Libro do Consello de Pontevedra" (1431-1453), Museo de Pontevedra, 1989.

ROMANI MARTÍNEZ (Miguel), Colección diplomatica do mosteiro cisterciense de Santa Maria de Meira (Orense) 1025-1310, Santiago, 2 vols., 1989.

SÁNCHEZ BELDA (Luis), Guia del Archivo Histórico Nacional, Madrid, D.G. de Archivos y Bibliotecas, 1958, Citado: AHN, Guia.

SiCART (Ángel), Pintura medieval. La miniatura, Col. Arte gallega Sánchez Cantón,

Santiago de C., 1981, 289 pp., láms. Citado: La miniatura.

Tranoy (A.), Vid. ARIAS Vilas, F.

VÁZQUEZ SACO (F.), Vid. Inscripciones romanas de Galicia, II.

VÁZQUEZ SEIJA (M.), Vid. Inscripciones romanas de Galicia, II.

VillaAmil y CASTRO (José), Los códices de las Iglesias de Galicia, RABM, III (1873), p. 283 ss., y IV (1874), p. 141 ss.

\section{RÉSUMÉ}

À partir d'une énumération des principales sources documentaries trouvées dans les archives nationales, régionales, écclésiastiques et locales sur la Galice, et à partir de manuscrits anciens, l'auteur essaie d'établir une synthèse de la paléographie galicienne. Il insiste sur les sources documentaires qui sont les plus nombreuses et les plus variées.

En suivant la ligne traditionnelle de l'évolution de l'écriture espagnole médiévale, il étudie les différentes étapes de son développement, depuis les traces que l'on peut trouver pendant la période romaine et wisigothe, jusqu'au début du XVIème siècle. Il étudie principalement l'écriture wisigothe pour le plus grand intérêt de ses sigularités, et ensuite les autres périodes paléographiques que les traités les plus traditionnels signalent.

Il tente d'étudier, pour chaque période, le milieu culturel, les textes du Codex existants et la morphologie des écritures représentées afin de faire ressortir l'évolution harmonieuse de l'écriture pendant la période étudiée.

\section{SUMMARY}

From an enumeration of the principal documental contents of codex related to Galicia, to be found in the regional, ecclesiastical and local National Archives, the author tries to establish a summary of Palaeography in Galicia. The author focuses the attention on the documental contents because they are the most numerous and varied.

Following a traditional line of evolution of the Spanish medieval script, he studies the different steps of its development, from the indications that are found in the roman and visigothic periods to the beginning of the XVI ${ }^{\text {th }}$ century. 
The author specially studies the visigothic script as it is the most interesting one for its particularities, and then the other palaeographic periods mentioned in the most time-honoured treaties.

In each period, he tries to study the cultural atmosphere, the well-preserved codex and the morphology of the represented scripts to obtain the harmonic evolution of the script of the historical period treated in this study. 